Article

\title{
Sulfadiazine Salicylaldehyde-Based Schiff Bases: Synthesis, Antimicrobial Activity and Cytotoxicity
}

\author{
Martin Krátký ${ }^{1, *}$, Magdaléna Dzurková ${ }^{2}$, Jiří Janoušek ${ }^{3}$, Klára Konečná ${ }^{4}$, František Trejtnar ${ }^{3}$, \\ Jiřina Stolaříková ${ }^{5}$ and Jarmila Vinšová ${ }^{1}$ \\ 1 Department of Organic and Bioorganic Chemistry, Faculty of Pharmacy in Hradec Králové, \\ Charles University, Akademika Heyrovského 1203, 50005 Hradec Králové, Czech Republic; \\ vinsova@faf.cuni.cz \\ 2 Department of Chemistry, Faculty of Science, J. E. Purkinje University, České mládeže 8, \\ 40096 Ústí nad Labem, Czech Republic; dzurkova.magda@seznam.cz \\ 3 Department of Pharmacology and Toxicology, Faculty of Pharmacy, Charles University, \\ Akademika Heyrovského 1203, 50005 Hradec Králové, Czech Republic; janousj2@faf.cuni.cz (J.J.); \\ trejnarf@faf.cuni.cz (F.T.) \\ 4 Department of Biological and Medical Sciences, Faculty of Pharmacy, Charles University, \\ Akademika Heyrovského 1203, 50005 Hradec Králové, Czech Republic; konecna@faf.cuni.cz \\ 5 Laboratory for Mycobacterial Diagnostics and Tuberculosis, Regional Institute of Public Health in Ostrava, \\ Partyzánské náměstí 7, 70200 Ostrava, Czech Republic; Jirina.Stolarikova@zu.cz \\ * Correspondence: martin.kratky@faf.cuni.cz; Tel.: +420-495067343; Fax: +420-495067166
}

Received: 25 August 2017; Accepted: 13 September 2017; Published: 19 September 2017

\begin{abstract}
The resistance among microbes has brought an urgent need for new drugs. Thus, we synthesized a series of Schiff bases derived from the sulfa drug sulfadiazine and various salicylaldehydes. The resulting 4-[(2-hydroxybenzylidene)amino]- $N$ -(pyrimidin-2-yl)benzene-sulfonamides were characterized and evaluated against Gram-positive and Gram-negative bacteria, yeasts, moulds, Mycobacterium tuberculosis, nontuberculous mycobacteria (M. kansasii, M. avium) and their cytotoxicity was determined. Among bacteria, the genus Staphylococcus, including methicillin-resistant $S$. aureus, showed the highest susceptibility, with minimum inhibitory concentration values from $7.81 \mu \mathrm{M}$. The growth of Candida sp. and Trichophyton interdigitale was inhibited at concentrations starting from $1.95 \mu \mathrm{M}$. 4-[(2,5-Dihydroxybenzylidene)amino]-N-(pyrimidin-2-yl)-benzenesulfonamide was identified as the most selective Schiff base for these strains with no apparent cytotoxicity and a selectivity index higher than 16 . With respect to $M$. tuberculosis and $M$. kansasii that were inhibited within the range of 8 to $250 \mu \mathrm{M}$, unsubstituted 4-[(2-hydroxy-benzylidene)amino]- $N$-(pyrimidin-2-yl)benzenesulfonamide meets the selectivity requirement. In general, dihalogenation of the salicylic moiety improved the antibacterial and antifungal activity but also increased the cytotoxicity, especially with an increasing atomic mass. Some derivatives offer more advantageous properties than the parent sulfadiazine, thus constituting promising hits for further antimicrobial drug development.
\end{abstract}

Keywords: antibacterial activity; antifungal activity; antimycobacterial activity; cytotoxicity; Schiff bases; sulfadiazine; sulfonamides

\section{Introduction}

Schiff bases are condensation products of primary (aromatic) amines with aldehydes or ketones carrying the azomethine (imino) moiety $(-\mathrm{CR}=\mathrm{N}-)$. They are considered versatile pharmacophores for various pharmacological activities where the azomethine group has been demonstrated to be critical to the bioactivity. For example, Schiff bases, whether of natural or non-natural origin, have exhibited promising antibacterial, antitubercular, antifungal, antiparasitic, antiviral, antioxidant, anticancer, 
analgesic, anti-inflammatory properties etc. [1-3]. Altogether, they represent very frequently used and useful scaffold in medicinal chemistry.

Schiff bases of substituted salicylaldehydes (2-hydroxybenzaldehydes) are well-known antimicrobial agents in "free" form or as ligands in metallic complexes [4-7]. Similar biological action have been reported for Schiff bases of various sulfonamides [4,8,9]. In addition, cotrimoxazole, sulfamethoxazole and sulfadiazine (1, SDZ, Figure 1) have exhibited activity against Mycobacterium tuberculosis [10] as well as nontuberculous (atypical) mycobacteria (NTM) [11] at clinically achievable concentrations after administration per os. To the best of our knowledge, there is no report about an identical property of sulfathiazole, used now only topically, or other sulfonamides. El-Baradie reported [12] an antibacterial activity of a SDZ-based Schiff base with unsubstituted salicylaldehyde. It exhibited minimum inhibitory concentrations (MICs) of 100-250 $\mathrm{\mu g} / \mathrm{mL}$ for both Gram-positive and Gram-negative bacteria. The Schiff base derived from 5-bromosalicylaldehyde exhibited a broad spectrum of antibacterial and antifungal properties [13]. Isosteric 4-(5-chloro-2-hydroxybenzylideneamino)- $\mathrm{N}$-(pyrimidin-2-yl)benzenesulfonamide (2c, Figure 2) showed activity against Staphylococcus aureus, including a methicillin-resistant strain (MRSA), M. tuberculosis and Mycobacterium avium (MIC values within the range of 125-250 $\mu \mathrm{M}$ ) whereas it caused a significantly higher inhibition of Mycobacterium kansasii strains (8-32 $\mu \mathrm{M})$ [4].

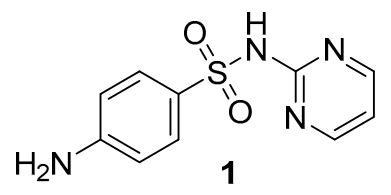

Figure 1. Sulfadiazine 1.

Keeping in mind these facts, we decided to combine two well-established pharmacophores for antimicrobial activity, sulfadiazine and salicylaldehyde, into one molecular Schiff base entity (Figure 2) and to screen systematically their antimicrobial and cytotoxic properties. In our study [4], the activities of sulfadiazine amides and imines based on the salicylic scaffold were comparable against the majority of mycobacterial strains and drug-susceptible Staphylococcus aureus, but further research discovered that the amides are significantly more toxic and less selective for eukaryotic cells. This research is justified also by an increasing resistance of microbes to current antimicrobial drugs.

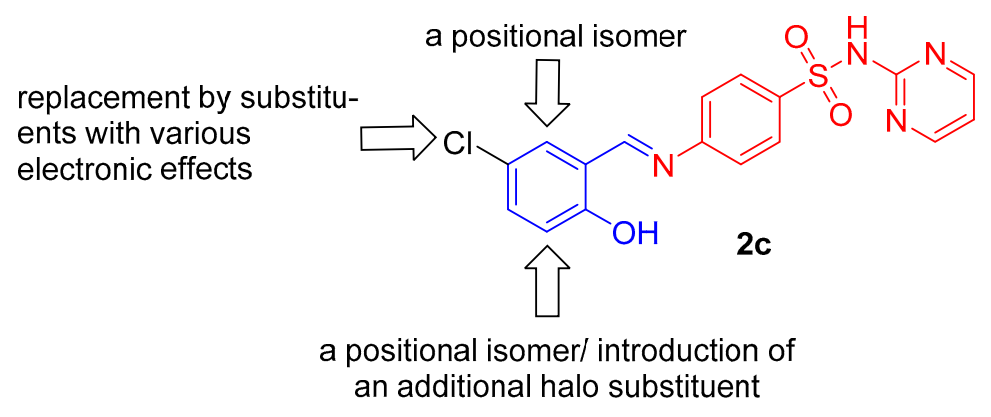

Figure 2. Rational design of novel Schiff bases combining sulfadiazine (red) and salicylaldehyde (blue) scaffolds based on structural modifications of $\mathbf{2 c}$.

Based on previous reports about 5-chlorosalicyladehyde-based Schiff bases [4,6], we designed compounds $2 \mathbf{a}$ without any substitution of the salicylic scaffold, with chlorine replaced by another halogen (5-F, $\mathrm{Br}$, I; negative inductive, $-\mathrm{I}$, and positive mesomeric, $+\mathrm{M}$, effects), other functional groups with different electronic properties: electron donating groups-alkyls $\left(\mathrm{CH}_{3}\right.$, tert-butyl), $\mathrm{OH}$ and $\mathrm{CH}_{3} \mathrm{O}$ as well as $\mathrm{NO}_{2}$ as an electron withdrawing group. Additionally, based on our previous report [4], we explored positional isomers of 4-[(5-chloro-2-hydroxybenzylidene)amino]- $N$-(pyrimidin-2-yl)-benzenesulfonamide 
(2c, 3-Cl, 6-Cl) and 3,5-dihalogen derivatives (3,5- $\mathrm{Cl}_{2}, 3,5-\mathrm{I}_{2}, 3-\mathrm{Br}-5-\mathrm{Cl}$ and 3-I-5-Cl). The drug design based on rational modifications of $2 \mathrm{c}$ is depicted in Figure 2. We also synthesized the Schiff base of 5-nitrofuran-2-carbaldehyde (5-nitrofurfural; 2q), a known pharmacophore for antimicrobial activity (e.g., [14,15]). This report is focused on chemical synthesis, characterization and initial biological evaluation (antimicrobial screening, toxicity for eukaryotic cells) to identify the most promising candidates for advanced microbiological and pharmacological tests.

\section{Results and Discussion}

\subsection{Chemistry}

Sulfadiazine-derived Schiff bases $\mathbf{2}$ were prepared by reactions of SDZ $\mathbf{1}$ and the corresponding aldehydes (salicylaldehydes, 5-nitrofuran-2-carbaldehyde) in boiling methanol $(\mathrm{MeOH})$ for $5 \mathrm{~h}$ (Scheme 1). Aldehydes were added to a hot methanolic suspension of SDZ. The poor solubility of $\mathrm{SDZ}$ in $\mathrm{MeOH}$ is a reason for an extended reaction time in contrast to previous work [4]. The yields were good, within the range of 85-95\%, with 4-[(2-hydroxy-5-nitrobenzylidene)amino]-N-(pyrimidin-2-yl)benzenesulfonamide (2f) being an exception (74\%). In this case, it was beneficial to dissolve 5-nitrosalicylaldehyde in hot $\mathrm{MeOH}$ and then add the sulfonamide; the reaction time was extended to $8 \mathrm{~h}$.

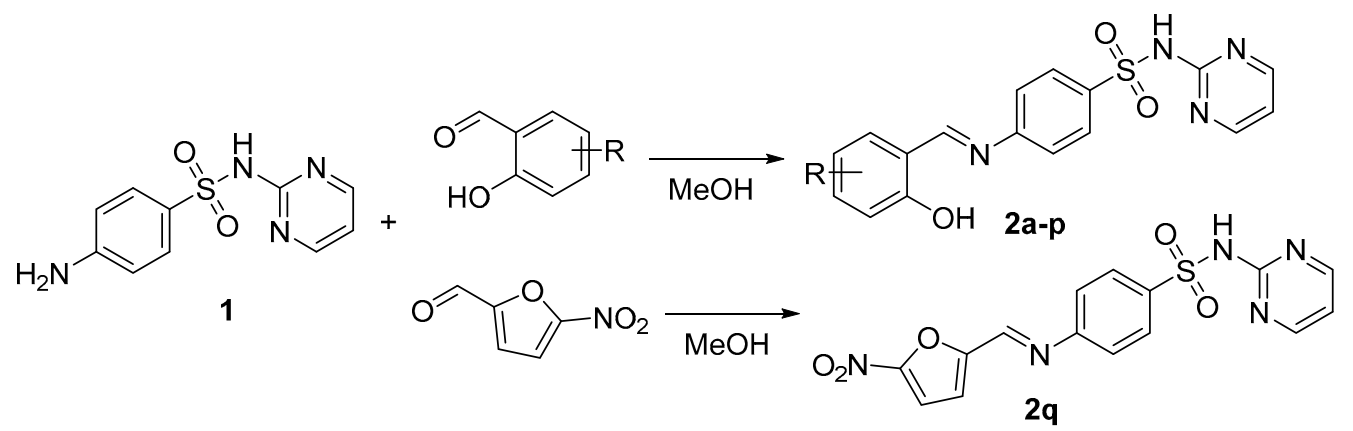

Scheme 1. Synthesis of sulfadiazine Schiff bases $2\left(\mathrm{MeOH}=\right.$ methanol; $\mathrm{R}=\mathrm{H}, 5-\mathrm{F}, 5-\mathrm{Cl}, 5-\mathrm{Br}, 5-\mathrm{I}, 5-\mathrm{NO}_{2}$, 5-Me, 5-MeO, 5-OH, 5-tert-Bu, 3-Cl, 6-Cl, 3,5- $\mathrm{Cl}_{2}$, 3-Br-5-Cl, 3-I-5-Cl, 3,5-I 2 ).

All of the compounds (Table 1 ) were characterized by ${ }^{1} \mathrm{H}-,{ }^{13} \mathrm{C}-\mathrm{NMR}, \mathrm{IR}$ spectra and melting points; their purity was checked additionally by elemental analysis. In the ${ }^{1} \mathrm{H}-\mathrm{NMR}$ spectra of Schiff bases 2 , an azomethine $(\mathrm{CH}=\mathrm{N})$ singlet appeared at 9.16-8.89 ppm. The phenolic hydrogen was observed in a comparatively broader range of 13.93-11.68 ppm. IR spectroscopy displayed a typical sharp and strong azomethine $(-\mathrm{CH}=\mathrm{N}-)$ band observed at $1582-1570 \mathrm{~cm}^{-1}$.

\subsection{Antimicrobial Activity}

The sulfadiazine derivatives 1-2 were screened in vitro for their antimicrobial properties. The panel of pathogens involved Staphylococcus aureus CCM 4516/08, methicillin-resistant Staphylococcus aureus H 5996/08 (MRSA), Staphylococcus epidermidis H 6966/08, Enterococcus faecalis J 14365/08 (Gram-positive bacteria), Escherichia coli CCM 4517, Klebsiella pneumoniae D 11750/08, extended spectrum beta-lactamase (ESBL)-positive Klebsiella pneumoniae J 14368/08, and Pseudomonas aeruginosa CCM 1961 (Gram-negative strains) (Table 1), mycobacteria Mycobacterium tuberculosis 331/88 $\left(\mathrm{H}_{37} \mathrm{Rv}\right)$, Mycobacterium avium 330/88, Mycobacterium kansasii 235/80 and the clinical isolate 6509/96 (Table 2) [16], and fungal species of Candida albicans ATCC 44859, Candida tropicalis 156, Candida krusei E28, Candida glabrata 20/I, Trichosporon asahii 1188, Aspergillus fumigatus 231, Lichtheimia corymbifera 272, and Trichophyton interdigitale 445 (Table 3) [17]. This panel of twenty microbial species covers a wide range of important human pathogens including those with an acquired resistance. It is a useful screening tool for an initial identification of potential antimicrobial activity of novel compounds. 
Table 1. Antibacterial activity of sulfadiazine derivatives 2.

\begin{tabular}{|c|c|c|c|c|c|c|c|c|c|c|c|c|c|c|c|c|c|}
\hline \multirow{3}{*}{ Code } & \multirow{3}{*}{$\mathbf{R}$} & \multicolumn{16}{|c|}{$\operatorname{MIC}(\mu \mathrm{M})$} \\
\hline & & \multicolumn{2}{|c|}{ SA } & \multicolumn{2}{|c|}{ MRSA } & \multicolumn{2}{|c|}{ SE } & \multicolumn{2}{|c|}{ EF } & \multicolumn{2}{|c|}{ EC } & \multicolumn{2}{|c|}{ KP } & \multicolumn{2}{|c|}{ KP-E } & \multicolumn{2}{|c|}{ PA } \\
\hline & & $24 \mathrm{~h}$ & $48 \mathrm{~h}$ & $24 \mathrm{~h}$ & $48 \mathrm{~h}$ & $24 \mathrm{~h}$ & $48 \mathrm{~h}$ & $24 \mathrm{~h}$ & $48 \mathrm{~h}$ & $24 \mathrm{~h}$ & $48 \mathrm{~h}$ & $24 \mathrm{~h}$ & $48 \mathrm{~h}$ & $24 \mathrm{~h}$ & $48 \mathrm{~h}$ & $24 \mathrm{~h}$ & $48 \mathrm{~h}$ \\
\hline $2 a$ & $\mathrm{H}$ & 500 & 500 & 250 & 250 & 62.5 & 62.5 & 31.25 & 62.5 & $>500$ & $>500$ & $>500$ & $>500$ & $>500$ & $>500$ & 500 & 500 \\
\hline $2 b$ & $5-\mathrm{F}$ & $>250$ & $>250$ & $>250$ & $>250$ & $>250$ & $>250$ & $>250$ & $>250$ & $>250$ & $>250$ & $>250$ & $>250$ & $>250$ & $>250$ & $>250$ & $>250$ \\
\hline $2 \mathrm{c}[4]$ & $5-\mathrm{Cl}$ & 250 & 250 & 125 & 125 & $>500$ & $>500$ & $>500$ & $>500$ & $>500$ & $>500$ & $>500$ & $>500$ & $>500$ & $>500$ & $>500$ & $>500$ \\
\hline $2 d$ & $5-\mathrm{Br}$ & 500 & 500 & 500 & 500 & 250 & 250 & $>500$ & $>500$ & 500 & 500 & 500 & 500 & 500 & 500 & 500 & 500 \\
\hline $2 e$ & $5-\mathrm{I}$ & 250 & 250 & 250 & 250 & 62.5 & 125 & 250 & 500 & 250 & 250 & 500 & 500 & 500 & 500 & 500 & 500 \\
\hline $2 f$ & $5-\mathrm{NO}_{2}$ & 250 & 250 & 250 & 250 & 500 & 500 & 500 & 500 & 250 & 250 & $>500$ & $>500$ & 500 & 500 & 500 & 500 \\
\hline $2 g$ & $5-\mathrm{CH}_{3}$ & $>250$ & $>250$ & 125 & 125 & 125 & 125 & $>250$ & $>250$ & $>250$ & $>250$ & $>250$ & $>250$ & $>250$ & $>250$ & $>250$ & $>250$ \\
\hline $2 \mathrm{~h}$ & $5-\mathrm{CH}_{3} \mathrm{O}$ & 500 & 500 & $>500$ & $>500$ & 62.5 & 62.5 & $>500$ & $>500$ & $>500$ & $>500$ & $>500$ & $>500$ & $>500$ & $>500$ & 500 & 500 \\
\hline $2 \mathbf{i}$ & 5-OH & 31.25 & 31.25 & 31.25 & 31.25 & 15.62 & 15.62 & 250 & 250 & 500 & 500 & $>500$ & $>500$ & $>500$ & $>500$ & 500 & 500 \\
\hline $2 j$ & 5-tert-Bu & $>125$ & $>125$ & $>125$ & $>125$ & $>125$ & $>125$ & $>125$ & $>125$ & $>125$ & $>125$ & $>125$ & $>125$ & $>125$ & $>125$ & $>125$ & $>125$ \\
\hline $2 \mathrm{k}$ & $6-\mathrm{Cl}$ & $>250$ & $>250$ & $>250$ & $>250$ & $>250$ & $>250$ & $>250$ & $>250$ & $>250$ & $>250$ & $>250$ & $>250$ & $>250$ & $>250$ & $>250$ & $>250$ \\
\hline 21 & $3-\mathrm{Cl}$ & $>500$ & $>500$ & $>500$ & $>500$ & $>500$ & $>500$ & $>500$ & $>500$ & $>500$ & $>500$ & $>500$ & $>500$ & $>500$ & $>500$ & $>500$ & $>500$ \\
\hline $2 m$ & $3,5-\mathrm{Cl}_{2}$ & 62.5 & 62.5 & 62.5 & 62.5 & 31.25 & 31.25 & $>500$ & $>500$ & $>500$ & $>500$ & $>500$ & $>500$ & 500 & 500 & $>500$ & $>500$ \\
\hline $2 n$ & $3-\mathrm{Br}-5-\mathrm{Cl}$ & 31.25 & 31.25 & 15.62 & 15.62 & 31.25 & 31.25 & $>500$ & $>500$ & 500 & 500 & $>500$ & $>500$ & 500 & 500 & $>500$ & $>500$ \\
\hline 20 & 3-I-5-Cl & 15.62 & 15.62 & 15.62 & 15.62 & 31.25 & 31.25 & 250 & 250 & 250 & 250 & 500 & 500 & 500 & 500 & 500 & 500 \\
\hline $2 p$ & $3,5-\mathrm{I}_{2}$ & 7.81 & 7.81 & 7.81 & 7.81 & 7.81 & 7.81 & 125 & 125 & 125 & 125 & 125 & 125 & 125 & 125 & 500 & 500 \\
\hline $2 q$ & - & 125 & 125 & 125 & 125 & 31.25 & 31.25 & $>500$ & $>500$ & $>500$ & $>500$ & 500 & 500 & 500 & 500 & 250 & 250 \\
\hline SDZ 1 & - & 500 & $>500$ & 500 & $>500$ & $>500$ & $>500$ & $>500$ & $>500$ & $>500$ & $>500$ & $>500$ & $>500$ & $>500$ & $>500$ & $>500$ & $>500$ \\
\hline BAC & - & 7.81 & 15.62 & 15.62 & 15.62 & 15.62 & 31.25 & 15.62 & 62.5 & $>500$ & $>500$ & $>500$ & $>500$ & $>500$ & $>500$ & $>500$ & $>500$ \\
\hline
\end{tabular}

BAC = bacitracin; SDZ = sulfadiazine. SA: Staphylococcus aureus CCM 4516/08; MRSA: methicillin-resistant Staphylococcus aureus H 5996/08; SE: Staphylococcus epidermidis H 6966/08;

EF: Enterococcus faecalis. J 14365/08. Escherichia coli CCM 4517, Klebsiella pneumoniae D 11750/08; ESBL-positive Klebsiella pneumoniae J 14368/08; PA: Pseudomonas aeruginosa CCM 1961. One or two of the best MIC value(s) for each strain are shown in bold. 
Table 2. Antimycobacterial activity of sulfadiazine derivatives 2.

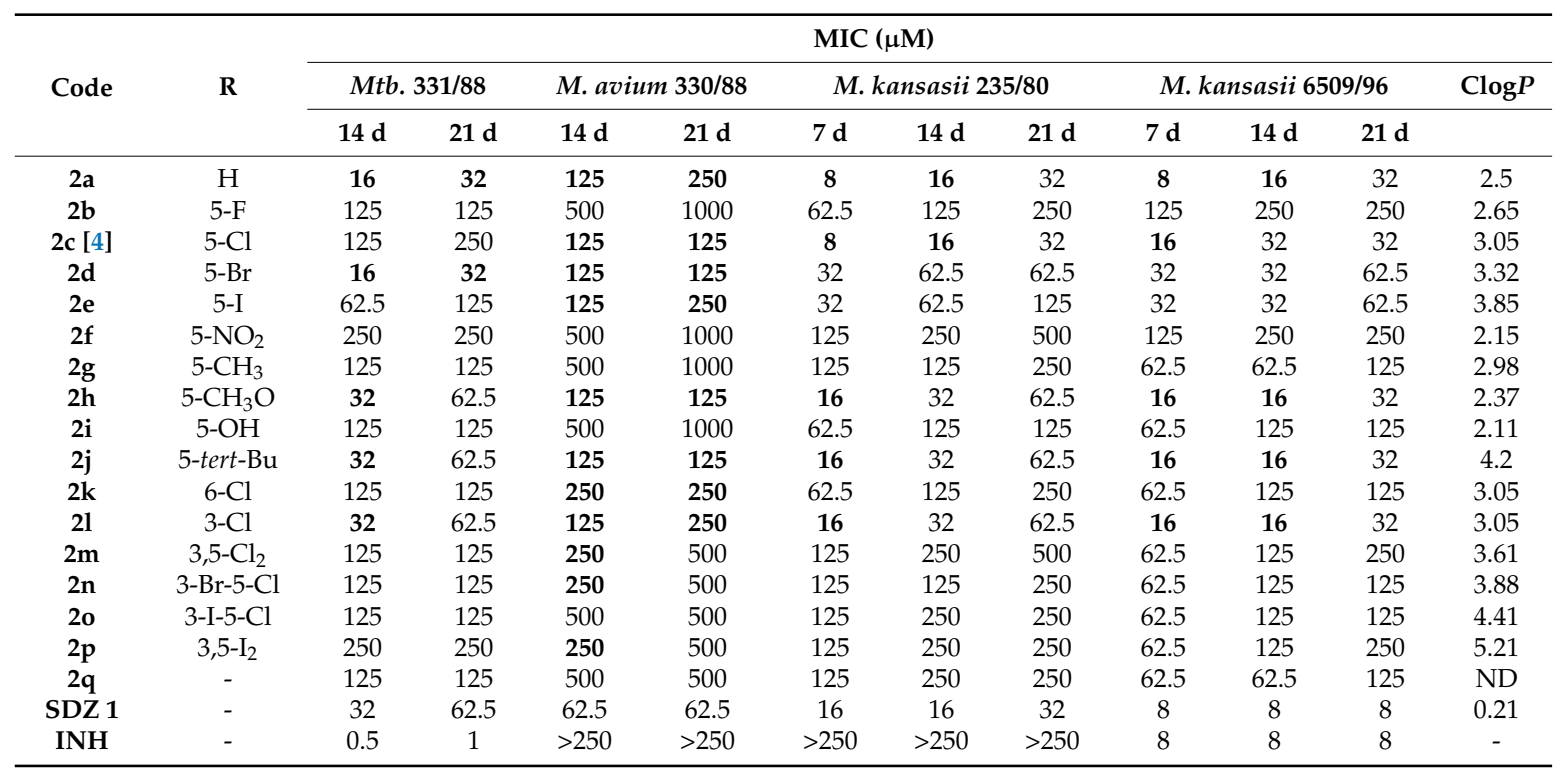

INH = isoniazid; SDZ = sulfadiazine. $M t b .=$ Mycobacterium tuberculosis. ND = not determined. One or two of the best MIC value(s) for each strain are shown in bold.

Bacitracin (BAC), fluconazole (FLU) and isoniazid (INH) were employed as the comparative drugs for antibacterial, antifungal and antimycobacterial activity, respectively. The parent sulfadiazine 1 showed only a weak action against both strains of Staphylococcus aureus (Table 1), and no antifungal properties, but it is an antimycobacterial agent (Table 2). Four Schiff bases (compounds $\mathbf{2 b}, \mathbf{2} \mathbf{j}-\mathbf{1}$ ) showed no significant antibacterial activity (Table 1). In general, the action against Gram-negative species is only negligible (MICs starting from $125 \mu \mathrm{M}$ ). 4-[(2-Hydroxy-3,5-diiodobenzylidene)amino]- $N$-(pyrimidin-2-yl)benzenesulfonamide (2p) showed the lowest MIC values, followed by other halogenated Schiff bases 2d, 2e, 2o. Among Gram-positive pathogens, Enterococcus was inhibited by six derivatives (compounds $2 \mathbf{a}, \mathbf{2 e}, \mathbf{2 f}, \mathbf{2 i}, \mathbf{2 0}, \mathbf{2 p}$ ) with 4-[(2-hydroxybenzylidene)amino]- $N$-(pyrimidin-2-yl)benzenesulfonamide (2a) showing superiority $(31.25 / 62.5 \mu \mathrm{M})$. Thus, the antibacterial properties are manifested especially for Staphylococci. MICs tend to be even lower for MRSA when compared to the methicillin-susceptible strain (e.g., 2g). For S. aureus, the 3,5-dihalogen substitution is translated into an enhanced activity (MICs of 7.81-62.5 $\mu \mathrm{M}$ ) where heavier atoms contribute to more intense action $(7.81-62.5 \mu \mathrm{M}$ ). Another substituent decreasing MIC values is a second hydroxyl group (i.e., 2i) in the para-position with respect to the salicylic hydroxyl with a uniform MIC of $31.25 \mu \mathrm{M}$. 
Table 3. Antifungal activity of sulfadiazine derivatives 2 .

\begin{tabular}{|c|c|c|c|c|c|c|c|c|c|c|c|c|c|c|c|c|c|}
\hline \multirow{3}{*}{ Code } & \multirow{3}{*}{$\mathbf{R}$} & \multicolumn{16}{|c|}{ MIC $(\mu \mathrm{M})$} \\
\hline & & \multicolumn{2}{|c|}{ CA } & \multicolumn{2}{|c|}{$\mathrm{CT}$} & \multicolumn{2}{|c|}{ CK } & \multicolumn{2}{|c|}{ CG } & \multicolumn{2}{|c|}{ TA } & \multicolumn{2}{|c|}{ AF } & \multicolumn{2}{|c|}{ LC } & \multicolumn{2}{|c|}{ TI } \\
\hline & & $24 \mathrm{~h}$ & $48 \mathrm{~h}$ & $24 \mathrm{~h}$ & $48 \mathrm{~h}$ & $24 \mathrm{~h}$ & $48 \mathrm{~h}$ & $24 \mathrm{~h}$ & $48 \mathrm{~h}$ & $24 \mathrm{~h}$ & $48 \mathrm{~h}$ & $24 \mathrm{~h}$ & $48 \mathrm{~h}$ & $24 \mathrm{~h}$ & $48 \mathrm{~h}$ & $72 \mathrm{~h}$ & $120 \mathrm{~h}$ \\
\hline $2 a$ & $\mathrm{H}$ & $>500$ & $>500$ & $>500$ & $>500$ & $>500$ & $>500$ & $>500$ & $>500$ & $>500$ & $>500$ & $>500$ & $>500$ & $>500$ & $>500$ & 125 & 125 \\
\hline $2 b$ & $5-\mathrm{F}$ & $>250$ & $>250$ & $>250$ & $>250$ & $>250$ & $>250$ & $>250$ & $>250$ & $>250$ & $>250$ & $>250$ & $>250$ & $>250$ & $>250$ & $>250$ & $>250$ \\
\hline $2 c[4]$ & $5-\mathrm{Cl}$ & 125 & 125 & $>500$ & $>500$ & $>500$ & $>500$ & 125 & 125 & 62.5 & 125 & $>500$ & $>500$ & $>500$ & $>500$ & $>500$ & $>500$ \\
\hline $2 d$ & $5-\mathrm{Br}$ & 125 & 125 & 250 & 250 & 250 & 250 & 62.5 & 62.5 & 62.5 & 62.5 & 250 & 250 & $>500$ & $>500$ & 62.5 & 62.5 \\
\hline $2 e$ & $5-\mathrm{I}$ & 62.5 & 125 & 125 & 125 & 62.5 & 125 & 62.5 & 62.5 & 125 & 125 & 250 & 250 & $>500$ & $>500$ & 31.25 & 31.25 \\
\hline $2 f$ & $5-\mathrm{NO}_{2}$ & 500 & 500 & $>500$ & $>500$ & $>500$ & $>500$ & 250 & 250 & $>500$ & $>500$ & $>500$ & $>500$ & 500 & 500 & 62.5 & 62.5 \\
\hline $2 g$ & $5-\mathrm{CH}_{3}$ & $>500$ & $>500$ & $>500$ & $>500$ & $>500$ & $>500$ & $>500$ & $>500$ & $>500$ & $>500$ & $>500$ & $>500$ & $>500$ & $>500$ & $>500$ & $>500$ \\
\hline $2 \mathrm{~h}$ & $5-\mathrm{CH}_{3} \mathrm{O}$ & 500 & 500 & 500 & 500 & $>500$ & $>500$ & 500 & 500 & 500 & 500 & $>500$ & $>500$ & $>500$ & $>500$ & 62.5 & 62.5 \\
\hline $2 \mathbf{i}$ & 5-OH & 15.62 & 15.62 & 15.62 & 15.62 & 31.25 & 31.25 & 15.62 & 15.62 & 15.62 & 15.62 & 125 & 125 & 500 & 500 & 1.95 & 1.95 \\
\hline $2 j$ & 5-tert-Bu & $>125$ & $>125$ & $>125$ & $>125$ & $>125$ & $>125$ & $>125$ & $>125$ & $>125$ & $>125$ & $>125$ & $>125$ & $>125$ & $>125$ & 62.5 & 62.5 \\
\hline $2 k$ & 6-Cl & $>250$ & $>250$ & $>250$ & $>250$ & $>250$ & $>250$ & $>250$ & $>250$ & $>250$ & $>250$ & $>250$ & $>250$ & $>250$ & $>250$ & $>250$ & $>250$ \\
\hline 21 & $3-\mathrm{Cl}$ & 62.5 & 62.5 & 125 & 125 & 250 & 250 & 125 & 125 & 125 & 125 & 250 & 250 & $>500$ & $>500$ & 31.25 & 31.25 \\
\hline $2 m$ & $3,5-\mathrm{Cl}_{2}$ & 62.5 & 62.5 & 125 & 125 & 62.5 & 62.5 & 31.25 & 31.25 & 62.5 & 62.5 & 250 & 250 & 500 & 500 & 125 & 125 \\
\hline $2 n$ & $3-\mathrm{Br}-5-\mathrm{Cl}$ & 31.25 & 31.25 & 62.5 & 62.5 & 62.5 & 62.5 & 31.25 & 31.25 & 62.5 & 62.5 & 250 & 250 & 500 & 500 & 62.5 & 62.5 \\
\hline 20 & 3-I-5-Cl & 7.81 & 7.81 & 7.81 & 7.81 & 7.81 & 7.81 & 7.81 & 7.81 & 7.81 & 7.81 & 62.5 & 62.5 & 250 & 250 & 1.95 & 1.95 \\
\hline $2 p$ & $3,5-\mathrm{I}_{2}$ & 3.9 & 3.9 & 7.81 & 7.81 & 7.81 & 7.81 & 3.9 & 3.9 & 3.9 & 3.9 & 62.5 & 62.5 & 62.5 & 62.5 & 15.62 & 15.62 \\
\hline $2 q$ & - & 250 & 250 & 250 & 250 & 250 & 250 & 250 & 250 & 500 & 500 & 500 & 500 & $>500$ & $>500$ & 250 & 250 \\
\hline FLU & - & 0.24 & 0.24 & $>500$ & $>500$ & 125 & 250 & 31.25 & 500 & 250 & 500 & $>500$ & $>500$ & $>500$ & $>500$ & 7.81 & 125 \\
\hline
\end{tabular}

FLU = fluconazole; SDZ = sulfadiazine 1. CA: Candida albicans ATCC 44859. CT: Candida tropicalis; CK: Candida krusei E28; CG: Candida glabrata 20/I. TA: Trichosporon asahii 1188; AF: Aspergillus fumigatus 231; LC: Lichtheimia corymbifera 272; TI: Trichophyton interdigitale 445. One or two of the best MIC value(s) for each strain are shown in bold. 
The rest of sulfadiazines 2 share MICs of $125-500 \mu \mathrm{M}$. The analysis of the effect of the chlorine position on the salicylic ring revealed that the activity is conferred by its presence at the position 5 while its shift to another carbon hampers antibacterial activity completely (2c vs. $2 \mathbf{k}-\mathbf{1})$. 3,5-Diiodosalicylidene sulfadiazine $2 \mathbf{p}$ was also superior for the inhibition of S. epidermidis $(7.81 \mu \mathrm{M})$, followed by $5-\mathrm{OH}(\mathbf{2} \mathbf{i}, 15.62 \mu \mathrm{M})$, other 3,5-dihalogen $(\mathbf{2 m}-\mathbf{o})$ and 5-nitrofuran $\mathbf{2 q}(31.25 \mu \mathrm{M})$ derivatives. The diiodo derivative $2 p$ was superior to bacitracin against $S$. epidermidis, and five compounds $(\mathbf{2} \mathbf{i}, \mathbf{2} \mathbf{m}-\mathbf{o}, \mathbf{2 q})$ were fully comparable. The activities of BAC and several Schiff bases (compounds $\mathbf{2 n}-\mathbf{p}$ ) are identical against $S$. aureus. Considering Enterococcus sp., the derivative 2a exhibited comparable MIC values.

All of the compounds 2 were able to inhibit both M. tuberculosis and NTM in vitro with MIC values within the range of $8-1000 \mu \mathrm{M}$. Both strains of $M$. kansasii showed the highest rate of susceptibility (MIC $\geq 8 \mu \mathrm{M}$ ), followed by $M$. tuberculosis $(\geq 16 \mu \mathrm{M}$ ) and M. avium (MIC values of $125-500 \mu \mathrm{M}$ ). The best results were obtained for the simplest derivative, 4-[(2-hydroxybenzylidene)amino]- $N$-(pyrimidin-2-yl)benzene-sulfonamide (2a) with MICs of 8-250 $\mu \mathrm{M}$ but for $M$. tuberculosis and both $M$. kansasii strains its MICs were $\leq 32 \mu \mathrm{M}$. A previously reported derivative of 5-chlorosalicylaldehyde [4] was efficient in vitro against NTM. Although 5-nitrofuran-2-yl is a well-established scaffold in drug design of potential anti-TB drugs [18], the 5-nitrofurylidene derivative $\mathbf{2 q}$ did not meet our expectation of excellent antimycobacterial action (MIC values $\geq 62.5 \mu \mathrm{M}$ ).

Structure-activity relationships for the substitution of the salicylidene fragment are reported in Table 4. In general, the introduction of any substituent does not offer any benefit when compared to unsubstituted Schiff base 2a. Among single halogens, bromine (compound 2d) is favourable, in the case of NTM strains concomitantly with 5- and 3-chloro isomers (compounds 2c, 21). 5-Methoxy (compound $2 \mathrm{~h}$ ) and tert-butyl (compound $2 \mathbf{j}$ ) groups contribute to the improved action, too. On the other hand, halo 3,5-disubstitution (compounds $\mathbf{2 m}-\mathbf{p}$ ), and a nitro group (compound $\mathbf{2 f}$ ) are detrimental for the inhibition of all mycobacteria. For NTM, a fluorine atom (compound 2b), 5-methyl (compound $\mathbf{2 g}$ ), or 5-nitrofurylidene (compound $\mathbf{2 q}$ ) abrogate the activity. Although lipophilicity represents an important factor influencing antimycobacterial action, no direct correlation between lipophilicity and MIC values was identified.

Table 4. SAR for the antimycobacterial activity.

\begin{tabular}{ccc}
\hline Strain & Improving Activity & Decreasing Activity \\
\hline M. tuberculosis & $\mathrm{H}, 5-\mathrm{Br}, 5-\mathrm{CH}_{3} \mathrm{O}, 5-t-\mathrm{Bu}, 3-\mathrm{Cl}$ & $5-\mathrm{Cl}, 5-\mathrm{NO}_{2}, 3,5-\mathrm{I}_{2}$ \\
M. avium & $\mathrm{H}, 5-\mathrm{Cl}, 5-\mathrm{Br}, 5-\mathrm{I}, 5-\mathrm{CH}_{3} \mathrm{O}, 5-\mathrm{-}-\mathrm{Bu}, 3-\mathrm{Cl}$ & $5-\mathrm{F}, 5-\mathrm{NO}_{2}, 5-\mathrm{CH}_{3}, 5-\mathrm{OH}, 3-\mathrm{I}-5-\mathrm{Cl}, 5-\mathrm{NO}_{2}$-furylidene \\
M. kansasii & $\mathrm{H}, 5-\mathrm{Cl}, 5-\mathrm{Br}, 5-\mathrm{CH}_{3} \mathrm{O}, 5-t-\mathrm{Bu}, 3-\mathrm{Cl}$ & $5-\mathrm{F}, 5-\mathrm{NO}_{2}, 5-\mathrm{CH}_{3}, 3,5-\mathrm{X}_{2}, 3-\mathrm{X}-5-\mathrm{Cl}_{1}, 5-\mathrm{NO}_{2}$-furylidene \\
\hline
\end{tabular}

Drawing a comparison to INH, none of the Schiff bases 2 exceeded its activity against M. tuberculosis. For the clinical isolate M. kansasii 6509/96, five compounds (2a, 2c, 2h, 2j, and 21) were comparable after 7 and/or $14 \mathrm{~d}$ of incubation ( \pm one dilution). In contrast, eleven derivatives (2a, $\mathbf{2 c}-\mathbf{e}$, $\mathbf{2 h}, \mathbf{2} \mathbf{j}-\mathbf{n}, \mathbf{2 p}$ ) inhibited the growth of M. avium at the concentration of $250 \mu \mathrm{M}$ that is tolerated in the case of INH. Similarly, all of the derivatives 2 surpassed INH against M. kansasii 235/80.

Unfortunately, the modification of the parent sulfadiazine 1 to the derivatives $\mathbf{2}$ did not bring any significant improvement of antimycobacterial properties but the most active Schiff bases $(\mathbf{2} \mathbf{a}, \mathbf{2} \mathbf{d}, \mathbf{2} \mathbf{h}, \mathbf{2} \mathbf{j}$, and 21) exhibited activity comparable to that of $\mathbf{1}$ ( \pm one dilution).

Three Schiff bases (2b, 20, 2k) lacked antifungal activity (Table 3), two others (2a, $\mathbf{2} \mathbf{j})$ inhibited only T. interdigitale at 125 and $62.5 \mu \mathrm{M}$, respectively. Three derivatives showed MIC values against several strains starting from $250 \mu \mathrm{M}(\mathbf{2} \mathbf{f}, \mathbf{2 h}, \mathbf{2 q})$ with T. interdigitale being an exception (MIC of $62.5 \mu \mathrm{M}$ for $\mathbf{2 f}$ and $\mathbf{2 h}$ ). In general, this strain showed the highest susceptibility from all of the investigated fungi with MIC values of 1.95-250 $\mu$ M. 3-I-5- $\mathrm{Cl}(\mathbf{2 0}), 3,5-\mathrm{I}_{2}(\mathbf{2} \mathbf{p}), 5-\mathrm{OH}(\mathbf{2 j})$ were found as preferred substitution patterns for salicylic ring that are superior to FLU. Additional Schiff bases $(\mathbf{2} \mathbf{d}-\mathbf{f}, \mathbf{2} \mathbf{h}, \mathbf{2} \mathbf{j}, \mathbf{2} \mathbf{l}$, 
and 2n) produced lower MICs after $120 \mathrm{~h}$ of incubation. On the other hand, L. corymbifera is at least susceptible strain inhibited only by six derivatives $(2 \mathbf{f}, \mathbf{2 i}, \mathbf{2 m - p})$ with MICs $\geq 62.5 \mu \mathrm{M}$.

Nine compounds $\mathbf{2 d}, \mathbf{2} \mathbf{e}, \mathbf{2} \mathbf{i}$, and $\mathbf{2} \mathbf{l}-\mathbf{q}$ uniformly affected yeasts (Candida sp., T. asahii), three 5-substituted salicylidenesulfadiazines $\left(5-\mathrm{Cl} \mathbf{2} \mathbf{c}, 5-\mathrm{NO}_{2} \mathbf{2 f}\right.$, and $5-\mathrm{CH}_{3} \mathrm{O} \mathbf{2 h}$ ) were effective in vitro against only some strains. Similar to the antibacterial activity, dihalogen derivatives containing iodine $(\mathbf{2 o}-\mathbf{p}$, MICs of 3.9-7.81 $\mu \mathrm{M})$ or the second phenolic group $(2 \mathbf{i}, 15.62-31.25 \mu \mathrm{M})$ showed the highest in vitro potency, which was significantly superior to that of the fluconazole; C. albicans represented an exception. Satisfactory results are also conferred by 3,5-dichloro- and 3-bromo-5-iodo-salicylaldehyde scaffolds (compounds $2 \mathrm{~m}, 2 \mathrm{n}, 31.25-125 \mu \mathrm{M}$ ), followed by a single halogen $(\mathrm{Cl}, \mathrm{Br}, \mathrm{I})$ substitution pattern and it correlates positively with an increasing atomic mass and consequent lipophilicity. The comparison of isomeric monochlorinated Schiff bases (2c, 2k, 21) revealed the order: $3-\mathrm{Cl}(\mathbf{2} \mathbf{l})>5-\mathrm{Cl}(\mathbf{2 k})>6-\mathrm{Cl}$ (inactive $\mathbf{2 k}$ ).

Seeking insights into the potential mechanism of action, we evaluated the inhibition potency of selected salicylidenesulfonamides against isocitrate lyase, but they were virtually inactive in spite of the substitution pattern (i.e., their inhibition rates were lower than $10 \%$ at the single concentration of $100 \mu \mathrm{M})$.

\subsection{Cytotoxicity and Selectivity}

The cytotoxicity of the investigated compounds $\mathbf{1}$ and $\mathbf{2}$ was measured using the standard hepatic cell line HepG2 (Table 5) [16]. The used CellTiter 96 assay is based on the reduction of tetrazolium dye in living cells to formazan. This reduction is related to availability of NADH or NADPH. The parameter $\mathrm{IC}_{50}$, i.e., the concentration that reduces the viability of the cells to $50 \%$ of the maximal viability, was used as a measure of cytotoxicity. It was not possible to determine the exact $\mathrm{IC}_{50}$ values of two derivatives (compounds $\mathbf{2 a}, \mathbf{2} \mathbf{b}$ ) due to their limited solubility in the cell culture medium used in this experiment.

Table 5. Cytotoxicity for HepG2 cells and selectivity.

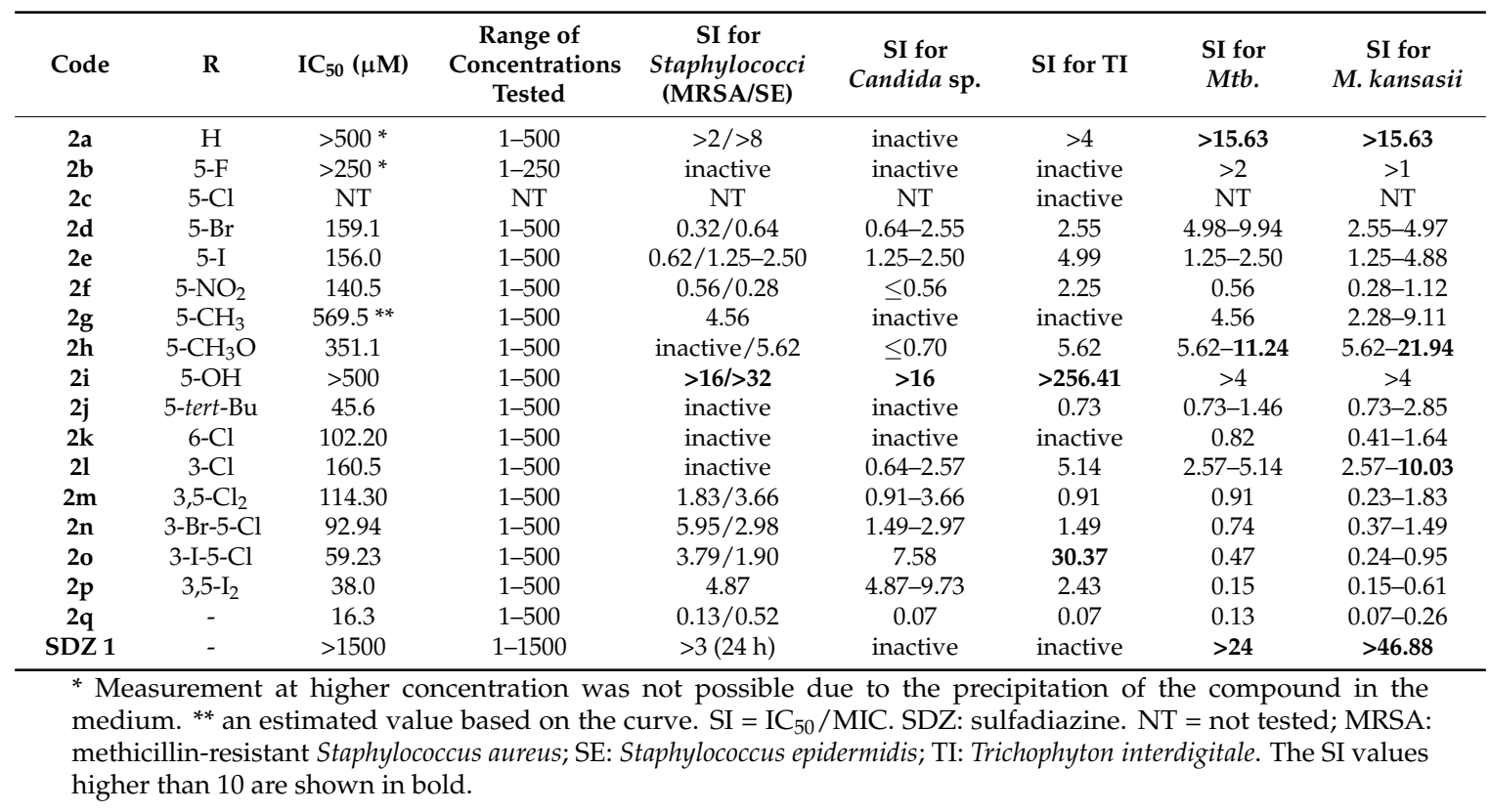

We can divide the investigated Schiff bases 2 into three groups according to their cytotoxicity for HepG2 cells. The first one covers comparatively non-toxic compounds 1, 2a, $\mathbf{2 b}$, and $2 \mathbf{g}-\mathbf{i}\left(\mathrm{IC}_{50}\right.$ values $\left.>250 \mu \mathrm{M}\right)$. The group of the compounds with an intermediate toxicity and $\mathrm{IC}_{50} \mathrm{~s}$ in the range of 102.2 to $160.5 \mu \mathrm{M}$ consists of $\mathbf{2 d - f}$, and $\mathbf{2 k} \mathbf{k}-\mathbf{m}$. The last 
group includes sulfonamides with an increased cytotoxicity $\left(\mathrm{IC}_{50} \leq 100 \mu \mathrm{M}: \mathbf{2 j}, \mathbf{2} \mathbf{n}-\mathbf{q}\right)$. 4-\{[(5-Nitrofuran-2-yl)methylene]amino\}- $N$-(pyrimidin-2-yl)benzene-sulfonamide (2q) was found to be the most toxic substance $\left(\mathrm{IC}_{50}=16.0 \mu \mathrm{M}\right)$. Obviously, the replacement of the salicyl ring by 5-nitrofuran-2-yl produced a more pronounced toxicity for mammalian cells. The majority of the modifications of the parent sulfadiazine $1\left(\mathrm{IC}_{50}>1500 \mu \mathrm{M}\right)$ increased the cytotoxicity by up to two orders of magnitude for the most toxic compounds. Generally, the enhanced cytotoxicity is observed in the presence of 3,5-halogen disubstitution and a tert-butyl moiety. Among particular halogens, the cytotoxicity correlates positively with an increased atomic mass. The presence of a non-bulky electron-donating group $\left(\mathrm{CH}_{3}, \mathrm{CH}_{3} \mathrm{O}, \mathrm{OH}\right)$ or hydrogen results in less cytotoxic compounds (i.e., $2 \mathbf{a}, \mathbf{2 g}-\mathbf{i}$ ).

We calculated the selectivity indices (SIs) for M. tuberculosis, both strains of M. kansasii, MRSA, S. epidermidis, all of the Candida species and T. interdigitale (Table 5). The SI is defined as the ratio of $\mathrm{IC}_{50}$ to $\mathrm{MIC}$, and values higher than 10 indicate rather acceptable toxicity (based on the analogy of the therapeutic index). Considering mycobacteria, in addition to the parent sulfadiazine 1, two compounds exhibited targeted selectivity: Unsubstituted salicylidene sulfadiazine $2 \mathrm{a}(\mathrm{SI}>15.63)$ followed by 5 -methoxy derivative $2 \mathrm{~h}$ after $14 \mathrm{~d}$ of the incubation. 3-Chlorosalicylaldehyde-based Schiff base $\mathbf{2 1}$ provided for M. kansasii a borderline SI value after 7 and $14 \mathrm{~d}$. 4-[(2,5-Dihydroxybenzylidene)amino]- $N$-(pyrimidin-2-yl)benzenesulfonamide (2i) showed the best safety profile for Staphylococci and fungi (>16), especially for the filamentous fungus T. interdigitale ( $>256.41)$. For this strain, the dihalogenated derivative 20 was selective too (SI $=30.37$ ).

\section{Materials and Methods}

\subsection{Chemistry}

\subsubsection{General Information}

All of the reagents and solvents were purchased from Sigma-Aldrich (St. Louis, MO, USA) or Penta Chemicals (Prague, Czech Republic) and were used as received. The reactions and the purity of the products were monitored by thin-layer chromatography (TLC) with a mixture of dichloromethane with $n$-hexane and methanol $(4: 3: 1, v / v)$ as the eluent. The plates were coated with $0.2 \mathrm{~mm}$ Merck 60 F254 silica gel (Merck Millipore, Darmstadt, Germany) and were visualised by UV irradiation $(254 \mathrm{~nm})$. The melting points were determined using a B-540 melting point apparatus (Büchi, Flawil, Switzerland) with open capillaries, and the reported values are uncorrected. The elemental analysis $(\mathrm{C}, \mathrm{H}, \mathrm{N})$ was performed with an automatic microanalyser instrument CHNS-O CE (Fisons EA 1110, Milano, Italy). The infrared spectra (ATR) were recorded on a Nicolet 6700 FT-IR spectrometer (ThermoFisher Scientific, Waltham, MA, USA) in the range of 600 to $4000 \mathrm{~cm}^{-1}$. The NMR spectra were measured in DMSO- $d_{6}$ at ambient temperature using a Varian VNMR S500 instrument $(500 \mathrm{MHz}$ for ${ }^{1} \mathrm{H}$ and $125 \mathrm{MHz}$ for ${ }^{13} \mathrm{C}$; Varian Inc., Palo Alto, CA, USA). The chemical shifts, $\delta$, are given in ppm with respect to tetramethylsilane as the internal standard. The coupling constants $(J)$ are reported in Hz. The calculated $\log P$ values $(\log P)$, which are the logarithms of the partition coefficients for octan-1-ol/water, were determined using the CS ChemOffice Ultra version 16.0 program (CambridgeSoft, Cambridge, MA, USA).

\subsubsection{Synthesis}

Sulfadiazine 1 ( $1 \mathrm{mmol}, 250.3 \mathrm{mg}$ ) was suspended in methanol $(\mathrm{MeOH}, 10 \mathrm{~mL})$, and $1.1 \mathrm{mmol}$ of the appropriate aldehyde was added in one portion under vigorous stirring. The solution was refluxed for $5 \mathrm{~h}$ and then stirred at room temperature overnight. The resulting crystals were filtered off, washed with a small amount of $\mathrm{MeOH}$ and then acetonitrile, and dried. The crystals were recrystallized from $\mathrm{MeOH}$ or tetrahydrofuran $/ n$-hexane mixture if necessary. The identity of known compounds (i.e., $2 \mathbf{a}, \mathbf{2 c}, \mathbf{2 d}$, and $\mathbf{2 m}$ ) was confirmed by NMR $\left({ }^{1} \mathrm{H}\right.$ and $\left.{ }^{13} \mathrm{C}\right)$ and IR spectroscopy. All spectroscopic 
characteristics were in accordance with previously reported data. The purity was checked additionally by melting points measurement and elemental analysis. The numbering of hydrogen atoms in the ${ }^{1} \mathrm{H}-\mathrm{NMR}$ spectra is depicted in Figure 3.<smiles>O=S(=O)(Nc1ncccn1)c1ccc(/N=C/c2ccccc2O)cc1</smiles>

Figure 3. Numbering of $\mathrm{H}$ atoms in NMR spectra.

4-[(2-Hydroxybenzylidene)amino]-N-(pyrimidin-2-yl)benzenesulfonamide (2a) [12,19]. Yellow solid; yield 94\%; m.p. 246-248.5 ${ }^{\circ} \mathrm{C}$ (lit. [19] 244-245 ${ }^{\circ} \mathrm{C}$ decomp.). IR: 3033, 2937, 2870, 2812, 2740, 1621, 1581 $(-\mathrm{HC}=\mathrm{N}-), 1493,1446,1413,1382,1339,1279,1188,1165,1151,1091,943,914,856,835,798,778,755$, 707, $667 \mathrm{~cm}^{-1} .{ }^{1} \mathrm{H}-\mathrm{NMR}: \delta 12.50(1 \mathrm{H}, \mathrm{s}, \mathrm{OH}), 11.86\left(1 \mathrm{H}, \mathrm{s}, \mathrm{SO}_{2} \mathrm{NH}\right), 8.95(1 \mathrm{H}, \mathrm{s}, \mathrm{CH}=\mathrm{N}), 8.51(2 \mathrm{H}, \mathrm{d}$, $\left.J=4.9 \mathrm{~Hz}, \mathrm{H}^{\prime \prime}{ }^{\prime}, \mathrm{H}^{\prime \prime}{ }^{\prime \prime}\right), 8.06-8.02\left(2 \mathrm{H}, \mathrm{m}, \mathrm{H} 2^{\prime}, \mathrm{H}^{\prime}\right), 7.68(1 \mathrm{H}, \mathrm{dd}, J=7.7 \mathrm{~Hz}, J=1.6 \mathrm{~Hz}, \mathrm{H} 6), 7.56-7.52$ $\left(2 \mathrm{H}, \mathrm{m}, \mathrm{H} 3^{\prime}, \mathrm{H}^{\prime}\right), 7.44(1 \mathrm{H}, \mathrm{dd}, J=7.8 \mathrm{~Hz}, J=1.7 \mathrm{~Hz}, \mathrm{H} 4), 7.06\left(1 \mathrm{H}, \mathrm{t}, J=4.9 \mathrm{~Hz}, \mathrm{H} 5^{\prime \prime}\right), 7.00-6.96(2 \mathrm{H}, \mathrm{m}$, H3, H5). ${ }^{13}$ C-NMR: $\delta$ 165.49, 160.41, 158.54, 157.03, 152.40, 138.16, 134.17, 132.72, 129.24, 121.88, 119.53, 119.48, 116.88, 115.98. Anal. Calcd. for $\mathrm{C}_{17} \mathrm{H}_{14} \mathrm{~N}_{4} \mathrm{O}_{3} \mathrm{~S}$ (354.38): C, 57.62; H, 3.98; N, 15.81. Found: C, $57.71 ; \mathrm{H}, 4.08 ; \mathrm{N}, 15.65$.

4-[(5-Fluoro-2-hydroxybenzylidene)amino]-N-(pyrimidin-2-yl)benzenesulfonamide (2b). Yellowish-orange solid; yield 92\%; m.p. 273-276 ${ }^{\circ} \mathrm{C}$ (decomp.). IR: 3032, 2939, 2870, 2812, 2736, 1570 (-HC=N-), 1483, 1444, 1414, 1338, 1269, 1251, 1220, 1163, 1144, 1091, 943, 879, 860, 835, 798, 776, 702, $669 \mathrm{~cm}^{-1} .{ }^{1} \mathrm{H}-\mathrm{NMR}$ : $\delta 12.07(1 \mathrm{H}, \mathrm{s}, \mathrm{OH}), 11.86\left(1 \mathrm{H}, \mathrm{s}, \mathrm{SO}_{2} \mathrm{NH}\right), 8.90(1 \mathrm{H}, \mathrm{s}, \mathrm{CH}=\mathrm{N}), 8.51\left(2 \mathrm{H}, \mathrm{d}, J=4.8 \mathrm{~Hz}, \mathrm{H}^{\prime \prime}{ }^{\prime \prime} \mathrm{H}^{\prime \prime}\right)$, 8.07-8.02 (2H, m, H2' $\left.\mathrm{H}^{\prime}\right), 7.55-7.49\left(3 \mathrm{H}, \mathrm{m}, \mathrm{H} 6, \mathrm{H}^{\prime}, \mathrm{H}^{\prime}\right), 7.31(\mathrm{dd}, J=8.8 \mathrm{~Hz}, J=3.2 \mathrm{~Hz}, \mathrm{H} 4), 7.06$ $\left(1 \mathrm{H}, \mathrm{t}, J=4.9 \mathrm{~Hz}, \mathrm{H}^{\prime \prime}\right), 7.01-6.98(1 \mathrm{H}, \mathrm{m}, \mathrm{H} 3) .{ }^{13} \mathrm{C}-\mathrm{NMR}: \delta 163.68(\mathrm{~d}, J=2.5 \mathrm{~Hz}), 158.54,157.01,156.54$, $155.18(\mathrm{~d}, J=235.1 \mathrm{~Hz}), 152.55,138.31,129.25,121.84,121.11(\mathrm{~d}, J=23.6 \mathrm{~Hz}), 119.96(\mathrm{~d}, J=7.6 \mathrm{~Hz})$, $118.36(\mathrm{~d}, J=7.6 \mathrm{~Hz}), 116.68(\mathrm{~d}, J=23.4 \mathrm{~Hz}), 112.28$. Anal. Calcd. for $\mathrm{C}_{17} \mathrm{H}_{13} \mathrm{FN}_{4} \mathrm{O}_{3} \mathrm{~S}$ (372.37): C, 54.83; H, 3.52; N, 15.05. Found: C, 54.90; H, 3.78; N, 14.94 .

4-[(5-Chloro-2-hydroxybenzylidene)amino]-N-(pyrimidin-2-yl)benzenesulfonamide (2c) [4]

4-[(5-Bromo-2-hydroxybenzylidene)amino]-N-(pyrimidin-2-yl)benzenesulfonamide (2d) [13]. Orange solid; yield 89\%; m.p. 273.5-275.5 ${ }^{\circ} \mathrm{C}$ (lit. [13] 246-248 ${ }^{\circ} \mathrm{C}$ ). Anal. Calcd. for $\mathrm{C}_{17} \mathrm{H}_{13} \mathrm{BrN}_{4} \mathrm{O}_{3} \mathrm{~S}$ (433.28): C, 47.13; $\mathrm{H}, 3.02 ; \mathrm{N}, 12.93$. Found: $\mathrm{C}, 46.97 ; \mathrm{H}, 3.21 ; \mathrm{N}, 13.04$.

4-[(2-Hydroxy-5-iodobenzylidene)amino]-N-(pyrimidin-2-yl)benzenesulfonamide (2e). Orange solid; yield 92\%; m.p. 273-274. $5^{\circ} \mathrm{C}$ (decomp.). IR: 3038, 2944, 2871, 2812, 2736, 1579 (-HC=N-), 1558, 1493, 1443, 1411, 1340, 1280, 1180, 1163, 1093, 945, 912, 860, 837, 823, 797, 783, 715, 671 cm ${ }^{-1} .{ }^{1} \mathrm{H}-\mathrm{NMR}: \delta 12.42$ $(1 \mathrm{H}, \mathrm{s}, \mathrm{OH}), 11.86\left(1 \mathrm{H}, \mathrm{s}, \mathrm{SO}_{2} \mathrm{NH}\right), 8.89(1 \mathrm{H}, \mathrm{s}, \mathrm{CH}=\mathrm{N}), 8.51\left(2 \mathrm{H}, \mathrm{d}, J=4.9 \mathrm{~Hz}, \mathrm{H} 4^{\prime \prime}, \mathrm{H}^{\prime \prime}\right), 8.06-8.00$ $\left(3 \mathrm{H}, \mathrm{m}, \mathrm{H6}, \mathrm{H}^{\prime}{ }^{\prime}, \mathrm{H6} 6^{\prime}\right), 7.70(1 \mathrm{H}, \mathrm{dd}, J=8.7 \mathrm{~Hz}, J=2.3 \mathrm{~Hz}, \mathrm{H} 4), 7.54-7.49\left(2 \mathrm{H}, \mathrm{m}, \mathrm{H} 3^{\prime}, \mathrm{H}^{\prime}\right), 7.05(1 \mathrm{H}, \mathrm{t}$, $\left.J=4.9 \mathrm{~Hz}, \mathrm{H}^{\prime \prime}\right), 6.83(1 \mathrm{H}, \mathrm{d}, J=8.7 \mathrm{~Hz}, \mathrm{H} 3) .{ }^{13} \mathrm{C}-\mathrm{NMR}: \delta 163.59,159.90,158.53,157.01,152.34,141.93$, $139.88,138.32,129.24,122.12,121.89,119.64,112.29,81.10$. Anal. Calcd. for $\mathrm{C}_{17} \mathrm{H}_{13} \mathrm{IN}_{4} \mathrm{O}_{3} \mathrm{~S}(480.28)$ : C, $42.51 ; \mathrm{H}, 2.73 ; \mathrm{N}, 11.67$. Found: $\mathrm{C}, 42.33 ; \mathrm{H}, 2.60 ; \mathrm{N}, 11.89$.

4-[(2-Hydroxy-5-nitrobenzylidene)amino]-N-(pyrimidin-2-yl)benzenesulfonamide (2f). Yellowish-orange solid; yield 74\%; m.p. 277-279 ${ }^{\circ} \mathrm{C}$ (decomp.). IR: 3045, 2733, 1581 (-HC=N-), 1530, 1487, 1444, 1411, 1340, 1338, 1298, 1161, 1093, 946, 840, 808, 785, 753, 733, $673 \mathrm{~cm}^{-1} .{ }^{1} \mathrm{H}-\mathrm{NMR}: \delta 13.51(1 \mathrm{H}, \mathrm{s}, \mathrm{OH}), 11.87$ $\left(1 \mathrm{H}, \mathrm{s}, \mathrm{SO}_{2} \mathrm{NH}\right), 9.10(1 \mathrm{H}, \mathrm{s}, \mathrm{CH}=\mathrm{N}), 8.69(1 \mathrm{H}, \mathrm{d}, J=2.9 \mathrm{~Hz}, \mathrm{H} 6), 8.52\left(2 \mathrm{H}, \mathrm{d}, J=4.9 \mathrm{~Hz}, \mathrm{H}^{\prime \prime}, \mathrm{H}^{\prime \prime}\right), 8.29$ $(1 \mathrm{H}, \mathrm{dd}, J=9.1 \mathrm{~Hz}, J=2.9 \mathrm{~Hz}, \mathrm{H} 4), 8.09-8.03\left(2 \mathrm{H}, \mathrm{m}, \mathrm{H} 2^{\prime}, \mathrm{H}^{\prime}\right), 7.60-7.55\left(2 \mathrm{H}, \mathrm{m}, \mathrm{H} 3^{\prime}, \mathrm{H}^{\prime}\right), 7.16(1 \mathrm{H}, \mathrm{d}$, 
$J=9.1 \mathrm{~Hz}, \mathrm{H} 3), 7.06\left(1 \mathrm{H}, \mathrm{t}, J=4.9 \mathrm{~Hz}, \mathrm{H} 5^{\prime \prime}\right) .{ }^{13} \mathrm{C}-\mathrm{NMR}: \delta 189.25,165.92,163.00,158.40,157.0,139.76$, $138.76,129.98,129.29,127.84,121.96,119.43,118.27,112.30$. Anal. Calcd. for $\mathrm{C}_{17} \mathrm{H}_{13} \mathrm{~N}_{5} \mathrm{O}_{5} \mathrm{~S}$ (399.38): C, 51.13; H, 3.28; N, 17.54. Found: C, 51.00; H, 3.11; N, 17.35.

4-[(2-Hydroxy-5-methylbenzylidene)amino]-N-(pyrimidin-2-yl)benzenesulfonamide (2g). Orange solid; yield 90\%; m.p. 255-258 ${ }^{\circ} \mathrm{C}$ (decomp.). IR: 3587 (O-H), 3035, 2807, 2737, 1576 (-HC=N-), 1491, 1441, 1409, 1378, 1343, 1284, 1263, 1207, 1185, 1157, 1094, 945, 877, 843, 817, 797, 786, 704, 680, $667 \mathrm{~cm}^{-1} .{ }^{1} \mathrm{H}-\mathrm{NMR}$ : $\delta 12.21(1 \mathrm{H}, \mathrm{s}, \mathrm{OH}), 11.82\left(1 \mathrm{H}, \mathrm{s}, \mathrm{SO}_{2} \mathrm{NH}\right), 8.89(1 \mathrm{H}, \mathrm{s}, \mathrm{CH}=\mathrm{N}), 8.51\left(2 \mathrm{H}, \mathrm{d}, J=4.9 \mathrm{~Hz}, \mathrm{H}^{\prime \prime}, \mathrm{H}^{\prime \prime}\right)$, 8.06-8.01 (2H, m, H2' $\left.{ }^{\prime} \mathrm{H}^{\prime}\right), 7.53-7.49\left(2 \mathrm{H}, \mathrm{m}, \mathrm{H}^{\prime}{ }^{\prime}, \mathrm{H}^{\prime}\right), 7.47(1 \mathrm{H}, \mathrm{d}, J=2.3 \mathrm{~Hz}, \mathrm{H6}), 7.25(\mathrm{dd}, J=8.4 \mathrm{~Hz}$, $J=2.1 \mathrm{~Hz}, \mathrm{H} 4) .7 .05\left(1 \mathrm{H}, \mathrm{t}, J=4.9 \mathrm{~Hz}, \mathrm{H}^{\prime \prime}\right), 6.88(1 \mathrm{H}, \mathrm{d}, J=8.4 \mathrm{~Hz}, \mathrm{H} 3), 2.26\left(3 \mathrm{H}, \mathrm{s}, \mathrm{CH}_{3}\right) .{ }^{13} \mathrm{C}-\mathrm{NMR}$ : $\delta 165.25,158.39,158.28,157.04,152.58,138.08,134.96,132.32,129.25,128.10,121.83,119.17,116.75$, 115.98, 20.08. Anal. Calcd. for $\mathrm{C}_{18} \mathrm{H}_{16} \mathrm{~N}_{4} \mathrm{O}_{3} \mathrm{~S}$ (368.41): C, 58.68; H, 4.38; N, 15.21. Found: C, 58.84; $\mathrm{H}, 4.22 ; \mathrm{N}, 15.41$.

4-[(2-Hydroxy-5-methoxybenzylidene)amino]-N-(pyrimidin-2-yl)benzenesulfonamide (2h). Orange-yellow solid; yield 86\%; m.p. $232-234{ }^{\circ} \mathrm{C}$. IR: 3030, 2734, 1576 (-HC=N-), 1487, 1440, 1410, 1338, 1268, 1215, 1153, 1087, 1035, 939, 876, 868, 852, 831, 820, 797, 754, 716, 694, $668 \mathrm{~cm}^{-1} .{ }^{1} \mathrm{H}-\mathrm{NMR}: \delta 12.25(1 \mathrm{H}, \mathrm{s}, \mathrm{OH})$, $11.83\left(1 \mathrm{H}, \mathrm{s}, \mathrm{SO}_{2} \mathrm{NH}\right), 8.91(1 \mathrm{H}, \mathrm{s}, \mathrm{CH}=\mathrm{N}), 8.51\left(2 \mathrm{H}, \mathrm{d}, J=4.9 \mathrm{~Hz}, \mathrm{H}^{\prime \prime}, \mathrm{H} 6^{\prime \prime}\right), 8.06-8.01\left(2 \mathrm{H}, \mathrm{m}, \mathrm{H} 2^{\prime}\right.$, $\left.\mathrm{H6}^{\prime}\right)$, 7.53-7.47 (2H, m, H3' $\left.\mathrm{H}^{\prime}\right), 7.27(1 \mathrm{H}, \mathrm{d}, J=3.1 \mathrm{~Hz}, \mathrm{H6}), 7.08-7.04\left(2 \mathrm{H}, \mathrm{m}, \mathrm{H} 4, \mathrm{H} 5^{\prime \prime}\right), 6.92(1 \mathrm{H}$, $\mathrm{d}, J=9.0 \mathrm{~Hz}, \mathrm{H} 3), 3.74\left(3 \mathrm{H}, \mathrm{s}, \mathrm{CH}_{3}\right) .{ }^{13} \mathrm{C}-\mathrm{NMR}: \delta 164.73,158.54,157.03,154.51,152.77,152.14,138.05$, $129.25,121.78,121.54,119.44,117.84,115.98,114.80,55.72$. Anal. Calcd. for $\mathrm{C}_{18} \mathrm{H}_{16} \mathrm{~N}_{4} \mathrm{O}_{4} \mathrm{~S}$ (384.41): C, 56.24; H, 4.20; N, 14.58. Found: C, 56.50; H, 4.31; N, 14.32 .

4-[(2,5-Dihydroxybenzylidene)amino]-N-(pyrimidin-2-yl)benzenesulfonamide (2i). Orange-yellow solid; yield 88\%; m.p. $247-249{ }^{\circ} \mathrm{C}$ (decomp.). IR: 3491 (O-H), 3032, 2939, 2811, 2730, $1573(-\mathrm{HC}=\mathrm{N}-), 1480$, $1447,1412,1359,1325,1280,1248,1208,1182,1142,1086,945,882,862,817,797,784,704,669 \mathrm{~cm}^{-1}$. ${ }^{1} \mathrm{H}-\mathrm{NMR}: \delta 11.84\left(1 \mathrm{H}, \mathrm{s}, \mathrm{SO}_{2} \mathrm{NH}\right), 11.68(1 \mathrm{H}, \mathrm{s}, 2-\mathrm{OH}), 9.13(1 \mathrm{H}, \mathrm{s}, \mathrm{CH}=\mathrm{N}), 8.84(1 \mathrm{H}, \mathrm{s}, 5-\mathrm{OH}), 8.51(2 \mathrm{H}$, $\left.\mathrm{d}, J=4.9 \mathrm{~Hz}, \mathrm{H}^{\prime \prime}{ }^{\prime}, \mathrm{H6}^{\prime \prime}\right), 8.06-7.99\left(2 \mathrm{H}, \mathrm{m}, \mathrm{H}^{\prime}{ }^{\prime}, \mathrm{H}^{\prime}\right), 7.53-7.45\left(2 \mathrm{H}, \mathrm{m}, \mathrm{H} 3^{\prime}, \mathrm{H}^{\prime}\right)$, 7.09-7.03 (2H, m, H6, $\left.\mathrm{H}^{\prime \prime}\right), 6.89(1 \mathrm{H}, \mathrm{dd}, J=8.8 \mathrm{~Hz}, J=3.0 \mathrm{~Hz}, \mathrm{H} 4), 6.81(1 \mathrm{H}, \mathrm{d}, J=8.8 \mathrm{~Hz}, \mathrm{H} 3) .{ }^{13} \mathrm{C}-\mathrm{NMR}: \delta 164.96,158.59$, 157.04, 153.30, 152.85, 149.92, 137.95, 129.21, 122.13, 121.82, 119.53, 117.55, 116.72, 115.98. Anal. Calcd. for $\mathrm{C}_{17} \mathrm{H}_{14} \mathrm{~N}_{4} \mathrm{O}_{4} \mathrm{~S}$ (370.38): C, 55.13; H, 3.81; N, 15.13. Found: C, 55.02; H, 3.65; N, 15.37 .

4-\{[5-(Tert-butyl)-2-hydroxybenzylidene]amino\}-N-(pyrimidin-2-yl)benzenesulfonamide (2j). Orange-yellow solid; yield 90\%; m.p. 267.5-270 ${ }^{\circ} \mathrm{C}$ (decomp.). IR: 3034, 2953, 1620, 1576 (-HC=N-), 1489, 1448, 1411, 1333, 1264, 1181, 1152, 1093, 953, 879, 839, 827, 798, 719, $671 \mathrm{~cm}^{-1} .{ }^{1} \mathrm{H}-\mathrm{NMR}: \delta 12.30(1 \mathrm{H}, \mathrm{s}, \mathrm{OH}), 11.83$ $\left(1 \mathrm{H}, \mathrm{s}, \mathrm{SO}_{2} \mathrm{NH}\right), 8.96(1 \mathrm{H}, \mathrm{s}, \mathrm{CH}=\mathrm{N}), 8.51\left(2 \mathrm{H}, \mathrm{d}, J=4.9 \mathrm{~Hz}, \mathrm{H} 4^{\prime \prime}, \mathrm{H} 6^{\prime \prime}\right), 8.06-8.00\left(2 \mathrm{H}, \mathrm{m}, \mathrm{H} 2^{\prime}, \mathrm{H}^{\prime}\right)$, $7.69(1 \mathrm{H}, \mathrm{d}, J=2.5 \mathrm{~Hz}, \mathrm{H6}), 7.55-7.51\left(2 \mathrm{H}, \mathrm{m}, \mathrm{H}^{\prime}, \mathrm{H}^{\prime}\right), 7.49(\mathrm{dd}, J=8.7 \mathrm{~Hz}, J=2.5 \mathrm{~Hz}, \mathrm{H} 4) .7 .06(1 \mathrm{H}$, $\left.\mathrm{t}, J=4.9 \mathrm{~Hz}, \mathrm{H}^{\prime \prime}\right), 6.91(1 \mathrm{H}, \mathrm{d}, J=8.7 \mathrm{~Hz}, \mathrm{H} 3), 1.27\left(9 \mathrm{H}, \mathrm{s}, \mathrm{CH}_{3}\right) .{ }^{13} \mathrm{C}-\mathrm{NMR}: \delta 166.16,158.86,158.56$, 157.32, 152.85, 141.97, 138.32, 131.83, 129.53, 129.20, 122.12, 119.00, 116.81, 112.58, 34.27, 31.60. Anal. Calcd. for $\mathrm{C}_{21} \mathrm{H}_{22} \mathrm{~N}_{4} \mathrm{O}_{3} \mathrm{~S}$ (410.49): C, 61.45; H, 5.40; N, 13.65. Found: C, 61.36; H, 5.28; N, 13.49.

4-[(2-Chloro-6-hydroxybenzylidene)amino]-N-(pyrimidin-2-yl)benzenesulfonamide (2k). Yellow solid; yield 86\%; m.p. 248-250 ${ }^{\circ} \mathrm{C}$ (decomp.). IR: 3032, 2943, 2810, 2734, 1580 (-HC=N-), 1489, 1446, 1408, 1339, 1277, $1177,1158,1092,945,929,864,849,822,797,780,734,724,670,652 \mathrm{~cm}^{-1} .{ }^{1} \mathrm{H}-\mathrm{NMR}: \delta 13.86(1 \mathrm{H}, \mathrm{s}, \mathrm{OH})$, $11.90\left(1 \mathrm{H}, \mathrm{s}, \mathrm{SO}_{2} \mathrm{NH}\right), 9.16(1 \mathrm{H}, \mathrm{s}, \mathrm{CH}=\mathrm{N}), 8.52\left(2 \mathrm{H}, \mathrm{d}, J=4.9 \mathrm{~Hz}, \mathrm{H}^{\prime \prime}{ }^{\prime}, \mathrm{H}^{\prime \prime}\right), 8.09-8.04\left(2 \mathrm{H}, \mathrm{m}, \mathrm{H} 2^{\prime}\right.$, $\left.\mathrm{H6}^{\prime}\right), 7.65-7.60\left(2 \mathrm{H}, \mathrm{m}, \mathrm{H} 3^{\prime}, \mathrm{H}^{\prime}\right), 7.45(1 \mathrm{H}, \mathrm{t}, J=8.2 \mathrm{~Hz}, \mathrm{H} 4), 7.10-7.04\left(2 \mathrm{H}, \mathrm{m}, \mathrm{H} 5, \mathrm{H} 5^{\prime \prime}\right), 6.98(1 \mathrm{H}, \mathrm{d}, J$ $=8.4 \mathrm{~Hz}, \mathrm{H} 3) .{ }^{13} \mathrm{C}-\mathrm{NMR}: \delta 162.72,162.55,158.54,156.98,151.00,138.91,135.90,135.11,129.29,122.19$, 120.50, 116.82, 115.99, 115.64. Anal. Calcd. for $\mathrm{C}_{17} \mathrm{H}_{13} \mathrm{ClN}_{4} \mathrm{O}_{3} \mathrm{~S}$ (388.83): C, 52.51; $\mathrm{H}, 3.37 ; \mathrm{N}, 14.41$. Found: C, 52.39; H, 3.39; N, 14.21 .

4-[(3-Chloro-2-hydroxybenzylidene)amino]-N-(pyrimidin-2-yl)benzenesulfonamide (21). Orange solid; yield 90\%; m.p. 265-266. ${ }^{\circ} \mathrm{C}$. IR: 3223, 3041, 2869, 1618, $1576(-\mathrm{HC}=\mathrm{N}-), 1489,1441,1409,1360,1338,1281$, 1202, 1182, 1151, 1115, 1091, 932, 845, 808, 792, 770, 741, $667 \mathrm{~cm}^{-1} .{ }^{1} \mathrm{H}-\mathrm{NMR}: \delta 13.77$ (1H, s, OH), 11.90 $\left(1 \mathrm{H}, \mathrm{s}, \mathrm{SO}_{2} \mathrm{NH}\right), 9.05(1 \mathrm{H}, \mathrm{s}, \mathrm{CH}=\mathrm{N}), 8.52\left(2 \mathrm{H}, \mathrm{d}, J=4.9 \mathrm{~Hz}, \mathrm{H}^{\prime \prime}{ }^{\prime}, \mathrm{H}^{\prime \prime}\right), 8.09-8.04\left(2 \mathrm{H}, \mathrm{m}, \mathrm{H} 2^{\prime}, \mathrm{H} 6^{\prime}\right)$, 
7.66-7.60 (4H, m, H4, H6, H3' $\left.{ }^{\prime} \mathrm{H}^{\prime}\right), 7.06\left(1 \mathrm{H}, \mathrm{t}, J=4.9 \mathrm{~Hz}, \mathrm{H}^{\prime \prime}\right), 7.01(1 \mathrm{H}, \mathrm{t}, J=7.8 \mathrm{~Hz}, \mathrm{H} 5) .{ }^{13} \mathrm{C}-\mathrm{NMR}$ : $\delta 165.91,158.55,156.99,156.52,150.86,138.78,133.91,132.28,129.25,122.10,120.55,120.18,119.96$, 115.97. Anal. Calcd. for $\mathrm{C}_{17} \mathrm{H}_{13} \mathrm{ClN}_{4} \mathrm{O}_{3} \mathrm{~S}$ (388.83): C, 52.51; H, 3.37; N, 14.41. Found: $\mathrm{C}, 52.60 ; \mathrm{H}, 3.21$; $\mathrm{N}, 14.61$.

4-[(3,5-Dichloro-2-hydroxybenzylidene)amino]-N-(pyrimidin-2-yl)benzenesulfonamide (2m) [20]. Orange solid; yield 86\%; m.p. $274-276{ }^{\circ} \mathrm{C}$ (decomp.; lit. [20] $260{ }^{\circ} \mathrm{C}$ from acetone). IR: 3036, 2722, 1582 $(-\mathrm{HC}=\mathrm{N}-), 1494,1453,1441,1410,1337,1265,1199,1182,1153,1092,947,890,869,843,798,742,727$, $673 \mathrm{~cm}^{-1} .{ }^{1} \mathrm{H}-\mathrm{NMR}: \delta 13.78(1 \mathrm{H}, \mathrm{s}, \mathrm{OH}), 11.91\left(1 \mathrm{H}, \mathrm{s}, \mathrm{SO}_{2} \mathrm{NH}\right), 9.01(1 \mathrm{H}, \mathrm{s}, \mathrm{CH}=\mathrm{N}), 8.51(2 \mathrm{H}, \mathrm{d}$, $\left.J=4.9 \mathrm{~Hz}, \mathrm{H}^{\prime \prime}{ }^{\prime}, \mathrm{H6}^{\prime \prime}\right), 8.09-8.04\left(2 \mathrm{H}, \mathrm{m}, \mathrm{H} 2^{\prime}, \mathrm{H}^{\prime}\right), 7.76(1 \mathrm{H}, \mathrm{d}, J=2.5 \mathrm{~Hz}, \mathrm{H} 4), 7.73(1 \mathrm{H}, \mathrm{d}, J=2.6 \mathrm{~Hz}$, H6), 7.63-7.58 (2H, m, H3' $\left.{ }^{\prime} \mathrm{H}^{\prime}\right), 7.06\left(1 \mathrm{H}, \mathrm{t}, J=4.9 \mathrm{~Hz}, \mathrm{H} 5^{\prime \prime}\right) .{ }^{13} \mathrm{C}-\mathrm{NMR}: \delta 164.77,158.51,156.96$, 155.68, 150.47, 139.09, 132.93, 131.07, 129.28, 122.58, 122.11, 121.90, 120.69, 115.91. Anal. Calcd. for $\mathrm{C}_{17} \mathrm{H}_{12} \mathrm{Cl}_{2} \mathrm{~N}_{4} \mathrm{O}_{3} \mathrm{~S}$ (423.27): C, 48.24; H, 2.86; N, 13.24. Found: C, 48.03; H, 2.74; N, 13.30.

4-[(3-Bromo-5-chloro-2-hydroxybenzylidene)amino]-N-(pyrimidin-2-yl)benzenesulfonamide (2n). Pale orange solid; yield 87\%; m.p. 253-256 ${ }^{\circ} \mathrm{C}$ (decomp.). IR: 3587 (O-H), 3032, 2938, 2807, 2729, 1581 (-HC=N-), 1489, 1443, 1411, 1338, 1294, 1279, 1199, 1184, 1159, 1092, 947, 869, 844, 793, 742, 723, 709, $675 \mathrm{~cm}^{-1}$. ${ }^{1} \mathrm{H}-\mathrm{NMR}: \delta 13.93(1 \mathrm{H}, \mathrm{s}, \mathrm{OH}), 11.91\left(1 \mathrm{H}, \mathrm{s}, \mathrm{SO}_{2} \mathrm{NH}\right), 8.99(1 \mathrm{H}, \mathrm{s}, \mathrm{CH}=\mathrm{N}), 8.51\left(2 \mathrm{H}, \mathrm{d}, J=4.9 \mathrm{~Hz}, \mathrm{H} 4{ }^{\prime \prime}\right.$, $\left.\mathrm{H}^{\prime \prime}\right), 8.09-8.04\left(2 \mathrm{H}, \mathrm{m}, \mathrm{H2}{ }^{\prime}, \mathrm{H}^{\prime}\right), 7.88(1 \mathrm{H}, \mathrm{d}, J=2.5 \mathrm{~Hz}, \mathrm{H} 4), 7.77(1 \mathrm{H}, \mathrm{d}, J=2.6 \mathrm{~Hz}, \mathrm{H6}), 7.65-7.59$ $\left(2 \mathrm{H}, \mathrm{m}, \mathrm{H3}{ }^{\prime}, \mathrm{H}^{\prime}\right), 7.06\left(1 \mathrm{H}, \mathrm{t}, J=4.9 \mathrm{~Hz}, \mathrm{H}^{\prime \prime}\right) .{ }^{13} \mathrm{C}-\mathrm{NMR}: \delta 164.83,158.53,156.96,156.67,150.32,139.10$, $135.71,131.80,129.28,122.97,122.15,120.41,115.95,111.33$. Anal. Calcd. for $\mathrm{C}_{17} \mathrm{H}_{12} \mathrm{BrClN}_{4} \mathrm{O}_{3} \mathrm{~S}(467.72)$ : C, 43.66; H, 2.59; N, 11.98. Found: C, 44.00; H, 2.61; N, 12.24 .

4-[(5-Chloro-2-hydroxy-3-iodobenzylidene)amino]-N-(pyrimidin-2-yl)benzenesulfonamide (2o). Orange solid; yield 92\%; m.p. 265-268 ${ }^{\circ} \mathrm{C}$ (decomp.). IR: $3566(\mathrm{O}-\mathrm{H}), 3041,2731,1580(-\mathrm{HC}=\mathrm{N}-), 1493,1439,1409$, 1340, 1290, 1264, 1182, 1153, 1090, 944, 868, 842, 797, 742, 701, $671 \mathrm{~cm}^{-1} .{ }^{1} \mathrm{H}-\mathrm{NMR}: \delta 11.89(1 \mathrm{H}, \mathrm{s}$, $\left.\mathrm{SO}_{2} \mathrm{NH}\right), 8.93(1 \mathrm{H}, \mathrm{s}, \mathrm{CH}=\mathrm{N}), 8.51\left(2 \mathrm{H}, \mathrm{d}, J=4.9 \mathrm{~Hz}, \mathrm{H}^{\prime \prime}{ }^{\prime \prime}, \mathrm{H}^{\prime \prime}\right), 8.10-8.03\left(2 \mathrm{H}, \mathrm{m}, \mathrm{H} 2^{\prime}, \mathrm{H}^{\prime}\right), 7.98(1 \mathrm{H}$, $\mathrm{d}, J=2.5 \mathrm{~Hz}, \mathrm{H} 4), 7.77(1 \mathrm{H}, \mathrm{d}, J=2.6 \mathrm{~Hz}, \mathrm{H6}), 7.65-7.58\left(2 \mathrm{H}, \mathrm{m}, \mathrm{H} 3^{\prime}, \mathrm{H}^{\prime}\right), 7.06\left(1 \mathrm{H}, \mathrm{t}, J=4.9 \mathrm{~Hz}, \mathrm{H}^{\prime \prime}\right)^{\prime}$. ${ }^{13}$ C-NMR: $\delta 164.83,159.14,158.38,156.96,150.30,141.35,132.54,129.96,129.27,123.42,122.17,119.24$, 112.29, 87.44. Anal. Calcd. for $\mathrm{C}_{17} \mathrm{H}_{12} \mathrm{ClIN}_{4} \mathrm{O}_{3} \mathrm{~S}$ (514.72): C, 39.67; H, 2.35; N, 10.89. Found: C, 39.89; $\mathrm{H}, 2.46 ; \mathrm{N}, 10.68$.

4-[(2-Hydroxy-3,5-diiodobenzylidene)amino]-N-(pyrimidin-2-yl)benzenesulfonamide (2p). Red solid; yield 95\%; m.p. 266-267.5 ${ }^{\circ} \mathrm{C}$ (decomp.). IR: 3567 (O-H), 3040, 1577 (-HC=N-), 1489, 1456, 1435, 1410, 1339, 1281, 1181, 1152, 1089, 932, 861, 833, 801, 743, 714, $662 \mathrm{~cm}^{-1} .{ }^{1} \mathrm{H}-\mathrm{NMR}: \delta 11.90\left(1 \mathrm{H}, \mathrm{s}, \mathrm{SO}_{2} \mathrm{NH}\right), 8.91$ $(1 \mathrm{H}, \mathrm{s}, \mathrm{CH}=\mathrm{N}), 8.51\left(2 \mathrm{H}, \mathrm{d}, J=4.9 \mathrm{~Hz}, \mathrm{H}^{\prime \prime}{ }^{\prime}, \mathrm{H}^{\prime \prime}\right), 8.17(1 \mathrm{H}, \mathrm{d}, J=2.1 \mathrm{~Hz}, \mathrm{H} 4), 8.08-8.04\left(2 \mathrm{H}, \mathrm{m}, \mathrm{H} 2^{\prime}\right.$, $\left.\mathrm{H}^{\prime}\right), 7.99(1 \mathrm{H}, \mathrm{d}, J=2.2 \mathrm{~Hz}, \mathrm{H} 6), 7.63-7.59\left(2 \mathrm{H}, \mathrm{m}, \mathrm{H} 3^{\prime}, \mathrm{H}^{\prime}\right), 7.06\left(1 \mathrm{H}, \mathrm{t}, J=4.9 \mathrm{~Hz}, \mathrm{H} 5^{\prime \prime}\right) .{ }^{13} \mathrm{C}-\mathrm{NMR}:$ $\delta$ 164.68, 159.98, 158.52, 156.96, 150.25, 149.04, 141.51, 138.99, 129.26, 122.15, 120.76, 115.91, 88.42, 81.67. Anal. Calcd. for $\mathrm{C}_{17} \mathrm{H}_{12} \mathrm{I}_{2} \mathrm{~N}_{4} \mathrm{O}_{3} \mathrm{~S}$ (606.18): $\mathrm{C}, 33.68 ; \mathrm{H}, 2.00 ; \mathrm{N}, 9.24$. Found: $\mathrm{C}, 33.47 ; \mathrm{H}, 2.14 ; \mathrm{N}, 8.97$.

4-\{[(5-Nitrofuran-2-yl)methylene]amino\}-N-(pyrimidin-2-yl)benzenesulfonamide (2q). Yellowish solid; yield 85\%; m.p. 207-209 ${ }^{\circ}$ C. IR: 3419, 2875, 1600, 1577 (-HC=N-), 1533, 1501, 1489, 1444, 1408, 1354, 1340, 1300, 1240, 1159, 1094, 1022, 970, 935, 831, 814, 803, 740, 722, 673, $659 \mathrm{~cm}^{-1} .{ }^{1} \mathrm{H}-\mathrm{NMR}: \delta 11.42(1 \mathrm{H}$, $\left.\mathrm{s}, \mathrm{SO}_{2} \mathrm{NH}\right), 8.49\left(2 \mathrm{H}, \mathrm{d}, J=4.9 \mathrm{~Hz}, \mathrm{H}^{\prime \prime}{ }^{\prime}, \mathrm{H6}^{\prime \prime}\right), 7.78-7.74\left(2 \mathrm{H}, \mathrm{m}, \mathrm{H} 2^{\prime}, \mathrm{H}^{\prime}\right), 7.73-7.69(2 \mathrm{H}, \mathrm{m}, \mathrm{CH}=\mathrm{N}$, furan H4), $7.02\left(1 \mathrm{H}, \mathrm{t}, J=4.9 \mathrm{~Hz}, \mathrm{H}^{\prime \prime}{ }^{\prime}\right), 6.95-6.90\left(2 \mathrm{H}, \mathrm{m}, \mathrm{H}^{\prime}, \mathrm{H}^{\prime}\right), 6.00(1 \mathrm{H}, \mathrm{d}, J=8.5 \mathrm{~Hz}$, furan $\mathrm{H} 3)$. ${ }^{13}$ C-NMR: $\delta 158.46,158.39,157.28,155.29,151.45,149.68,129.65,128.61,115.84,113.75,112.83,112.31$. Anal. Calcd. for $\mathrm{C}_{15} \mathrm{H}_{11} \mathrm{~N}_{5} \mathrm{O}_{5} \mathrm{~S}$ (373.34): C, 48.26; H, 2.97; N, 18.76. Found: $\mathrm{C}, 48.20 ; \mathrm{H}, 2.83 ; \mathrm{N}, 18.61$.

\subsection{Antimicrobial Activity}

\subsubsection{In Vitro Antibacterial Activity}

The antibacterial activities were assayed against four Gram-positive and four Gram-negative strains: Staphylococcus aureus CCM 4516/08, methicillin-resistant Staphylococcus aureus H 5996/08 
(MRSA), Staphylococcus epidermidis H 6966/08, Enterococcus faecalis J 14365/08; Escherichia coli CCM 4517, Klebsiella pneumoniae D 11750/08, extended-spectrum $\beta$-lactamase positive Klebsiella pneumoniae J 14368/08, and Pseudomonas aeruginosa CCM 1961. The microdilution broth method modified according to CLSI standard M07-A10 with Mueller-Hinton broth (HiMedia Laboratories, Mumbai, India) adjusted to $\mathrm{pH} 7.4( \pm 0.2)$ was used. The tested compounds were dissolved in DMSO to final concentrations ranging from 500 to $0.49 \mu \mathrm{M}$. Bacitracin (BAC) and sulfadiazine 1 were used as the reference drugs. A bacterial inoculum in sterile water was prepared to reach 0.5 according to McFarland scale $\left(1.5 \times 10^{8} \mathrm{CFU} / \mathrm{mL}\right)$. The minimum inhibitory concentrations were assayed as a reduction of growth compared to the control. The results were analysed visually. The MIC values were determined after 24 and $48 \mathrm{~h}$ of incubation in the dark at $35^{\circ} \mathrm{C}( \pm 0.1)$ in a humid atmosphere [16].

\subsubsection{In Vitro Antimycobacterial Activity}

The sulfadiazine derivatives 2 were evaluated to determine their in vitro antimycobacterial activity against Mycobacterium tuberculosis $331 / 88\left(\mathrm{H}_{37} \mathrm{Rv}\right.$; the dilution of this strain was $\left.10^{-3}\right)$, Mycobacterium avium 330/88 (resistant to INH, rifamycins, ofloxacin, and ethambutol; dilution of $10^{-5}$ ), and two strains of M. kansasii, namely 235/80 (dilution of $10^{-4}$ ) and the clinically isolated strain $6509 / 96$ (dilution of $10^{-5}$ ), using a previously described method [16]. The following concentrations were used: $1000,500,250,125,62.5,32,16,8,4,2$, and $1 \mu \mathrm{M}$. The MIC (reported in $\mu \mathrm{M}$ ) is the lowest concentration at which the complete inhibition of mycobacterial growth was observed. The MICs were determined after incubation at $37^{\circ} \mathrm{C}$ for 14 and $21 \mathrm{~d}$, for $\mathrm{M}$. kansasii additionally for $7 \mathrm{~d}$. Isoniazid (INH) and the parent sulfadiazine 1 were chosen as the reference drugs. The inhibition of isocitrate lyase was determined according to [21].

\subsubsection{In Vitro Antifungal Activity}

The antifungal properties were evaluated against four Candida strains (Candida albicans ATCC 44859, Candida tropicalis 156, Candida krusei E28, and Candida glabrata 20/I), Trichosporon asahii 1188 and three strains of filamentous fungi (Aspergillus fumigatus 231, Lichtheimia corymbifera 272, and Trichophyton interdigitale 445). The microdilution broth method with slight modifications was used according to the CLSI M27-A3 and M38-A2 guidelines in RPMI 1640 with glutamine (KlinLab, Prague, Czech Republic) buffered to $\mathrm{pH} 7.0$ with $0.165 \mathrm{~mol}$ of 3-morpholino-propane-1-sulphonic acid (Sigma-Aldrich). DMSO served as a diluent for all the compounds. In yeast, the final size of the inoculum was $5 \times 10^{3} \pm 0.2 \mathrm{CFU} / \mathrm{mL}$, and in the case of the moulds, the final size of the inoculum was $0.5-5 \times 10^{4} \mathrm{CFU} / \mathrm{mL}$. Fluconazole (FLU) was involved as the reference drug. The MIC values were assayed as inhibition of growth compared to the control. The results were analysed visually. The MIC values were determined after 24 and $48 \mathrm{~h}$ of incubation in the dark at $35{ }^{\circ} \mathrm{C}( \pm 0.1)$ in a humid atmosphere. For T. interdigitale, the final MIC values were determined after 72 and $120 \mathrm{~h}$ of incubation [17].

\subsection{Cytotoxicity Evaluation}

All of the compounds were tested to determine their cytotoxicity in the human hepatocellular liver carcinoma cell line HepG2 (passages 5-6 and 3-8; ECACC, Salisbury, UK) using a standard colorimetric method that involves measuring the reduction of a tetrazolium salt (CellTiter(R) 96 AQueous One Solution Cell Proliferation Assay; Promega, Fichtburg, MA, USA).

The cells were cultured in Minimum Essentials Eagle Medium (Sigma-Aldrich) supplemented with 10\% foetal bovine serum (PAA), 1\% L-glutamine solution (Sigma-Aldrich) and a non-essential amino acid solution (Sigma-Aldrich) in a humidified atmosphere containing $5 \% \mathrm{CO}_{2}$ at $37{ }^{\circ} \mathrm{C}$. The investigated compounds were dissolved in DMSO and a small volume was added to the cell culture. The tested compounds were prepared in triplicates at concentrations ranging from 1 to $1500 \mu \mathrm{M}$. Simultaneously, the following types of controls were also included in triplicates: determination of $100 \%$ viability and $0 \%$ viability (the cells were treated with 10\% DMSO), no cell control and vehiculum 
controls. After $24 \mathrm{~h}$ incubation in a humidified atmosphere containing $5 \% \mathrm{CO}_{2}$ at $37{ }^{\circ} \mathrm{C}$, the reagent from the kit CellTiter 96 was added. After $2 \mathrm{~h}$ incubation at $37^{\circ} \mathrm{C}$, absorbance of samples was recorded at $490 \mathrm{~nm}$ (Infinita M200, TECAN, Grödig, Austria). A standard toxicological parameter $\mathrm{IC}_{50}$ was calculated by nonlinear regression from a semilogarithmic plot of incubation concentration versus percentage of absorbance relative to untreated controls using GraphPad Prism 6 software (GraphPad Software Inc., San Diego, CA, USA). IC $_{50}$ is the inhibitory concentration that reduces the cell viability to $50 \%$ of the maximal (control) viability.

\section{Conclusions}

In conclusion, we identified several interesting structure-activity relationships in some novel sulfadiazine Schiff bases. Our findings suggested that several were selective for microbial pathogens (M. tuberculosis, M. kansasii, Staphylococcus spp. including one MRSA strain, yeasts and Trichophyton interdigitale). 4-[(2-Hydroxybenzylidene)amino]-N-(pyrimidin-2-yl)benzenesulfonamide (2a) is active in the inhibition of tuberculous and atypical mycobacteria. The 2,5-dihydroxybenzaldehyde-derived Schiff base $\mathbf{2} \mathbf{i}$ exhibited the highest selectivity for staphylococci and fungi. For these molecules, the desirable action is separated from an unwanted toxicity, thus constituting a promising hit for further structure optimization and development of potential antimicrobial agents. Further studies are required to gain a deeper understanding of their properties (especially mechanism of action and interactions with eukaryotic cells).

Acknowledgments: This work was supported by the Czech Science Foundation project No. 17-27514Y and the Charles University (Project SVV 260 414). The authors also thank the COST action CA15135 (Multitarget Paradigm for Innovative Ligand Identification in the Drug Discovery Process MuTaLig) for support. We would like to thank Ida Dufková for the excellent performance of antibiotic susceptibility tests, the staff of the Department of Organic and Bioorganic Chemistry, Faculty of Pharmacy, for the technical assistance and J. Urbanová, M.A., for the language help provided.

Author Contributions: This study was performed under the guidance of M.K. and J.V., they designed experiments. M.K. and M.D. synthesized and characterized the presented compounds. K.K. and J.S. were responsible for the antimicrobial evaluation, J.J. and F.T. for the cytotoxicity determination. M.K. and J.V. wrote the whole article, made discussion and conclusions.

Conflicts of Interest: The authors declare no conflict of interest.

\section{References}

1. Da Silva, C.M.; da Silva, D.L.; Modolo, L.V.; Alves, R.B.; de Resende, M.A.; Martins, C.V.B.; de Fátima, A. Schiff bases: A short review of their antimicrobial activities. J. Adv. Res. 2011, 2, 1-8. [CrossRef]

2. Qin, W.; Long, S.; Panunzio, M.; Biondi, S. Schiff Bases: A short survey on an evergreen chemistry tool. Molecules 2013, 18, 12264-12289. [CrossRef] [PubMed]

3. Kajal, A.; Bala, S.; Kamboj, S.; Sharma, N.; Saini, V. Schiff bases: A versatile pharmacophore. J. Catal. 2013, 2013. [CrossRef]

4. Krátký, M.; Vinšová, J.; Volková, M.; Buchta, V.; Trejtnar, F.; Stolaříková, J. Antimicrobial activity of sulfonamides containing 5-chloro-2-hydroxybenzaldehyde and 5-chloro-2-hydroxybenzoic acid scaffold. Eur. J. Med. Chem. 2012, 50, 433-440. [CrossRef] [PubMed]

5. Yıldız, M.; Tan, E.; Demir, N.; Yıldırım, N.; Ünver, H.; Kiraz, A.; Mestav, B. Synthesis and spectral, antimicrobial, anion sensing, and DNA binding properties of Schiff base podands and their metal complexes. Russ. J. Gen. Chem. 2015, 85, 2149-2162. [CrossRef]

6. Shi, L.; Ge, M.M.; Tan, S.H.; Li, H.Q.; Song, Y.C.; Zhu, H.L.; Tan, R.X. Synthesis and antimicrobial activities of Schiff bases derived from 5-chloro-salicylaldehyde. Eur. J. Med. Chem. 2007, 42, 558-564. [CrossRef] [PubMed]

7. Govindaraj, V.; Ramanathan, S. Synthesis, spectral characterisation, electrochemical, and fluorescence studies of biologically active novel Schiff base complexes derived from E-4-(2-hydroxy-3-methoxybenzlideneamino)- $N$-(pyrimidin-2-yl)benzenesulfonamide. Turk. J. Chem. 2014, 38, 521-530. [CrossRef] 
8. Mondal, S.; Mandal, S.M.; Mondal, T.K.; Sinha, C. Spectroscopic characterization, antimicrobial activity, DFT computation and docking studies of sulfonamide Schiff bases. J. Mol. Struct. 2017, 1127, 557-567. [CrossRef]

9. Chohan, Z.H.; Youssoufi, M.H.; Jarrahpour, A.; Hadda, T.B. Identification of antibacterial and antifungal pharmacophore sites for potent bacteria and fungi inhibition: Indolenyl sulfonamide derivatives. Eur. J. Med. Chem. 2010, 45, 1189-1199. [CrossRef] [PubMed]

10. Ameen, S.M.; Drancourt, M. In Vitro susceptibility of Mycobacterium tuberculosis to trimethoprim and sulfonamides in France. Antimicrob. Agents Chemother. 2013, 57, 6370-6371. [CrossRef] [PubMed]

11. Ameen, S.M.; Drancourt, M. In vitro susceptibility of Mycobacterium avium complex mycobacteria to trimethoprim and sulfonamides. Int. J. Antimicrob. Agents 2013, 42, 281-288. [CrossRef] [PubMed]

12. El-Baradie, K.Y. Preparation and characterization of sulfadiazine Schiff base complexes of Co(II), Ni(II), $\mathrm{Cu}(\mathrm{II})$, and Mn(II). Monatshefte Chem. 2005, 136, 1139-1155. [CrossRef]

13. Chohan, Z.H.; Shad, H.A.; Youssoufi, M.H.; Hadda, T.B. Some new biologically active metal-based sulphonamide. Eur. J. Med. Chem. 2010, 45, 2893-2901. [CrossRef] [PubMed]

14. Abdel-Aal, W.S.; Hassan, H.Y.; Aboul-Fadl, T.; Youssef, A.F. Pharmacophoric model building for antitubercular activity of the individual Schiff bases of small combinatorial library. Eur. J. Med. Chem. 2010, 45, 1098-1106. [CrossRef] [PubMed]

15. Zorzi, R.R.; Jorge, S.D.; Palace-Berl, F.; Pasqualoto, K.F.M.; de Sa Bortolozzo, L.; de Castro Siqueira, A.M.; Tavares, L.C. Exploring 5-nitrofuran derivatives against nosocomial pathogens: Synthesis, antimicrobial activity and chemometric analysis. Bioorg. Med. Chem. 2014, 22, 2844-2854. [CrossRef] [PubMed]

16. Krátký, M.; Vinšová, J.; Novotná, E.; Mandíková, J.; Trejtnar, F.; Stolaříková, J. Antibacterial activity of salicylanilide 4-(Trifluoromethyl)benzoates. Molecules 2013, 18, 3674-3688. [CrossRef] [PubMed]

17. Krátký, M.; Vinšová, J. Antifungal activity of salicylanilides and their esters with 4-(Trifluoromethyl)benzoic acid. Molecules 2012, 17, 9426-9442. [CrossRef] [PubMed]

18. Sriram, D.; Yogeeswari, P.; Dhakla, P.; Senthilkumar, P.; Banerjee, D.; Manjashetty, T.H. 5-Nitrofuran-2-yl derivatives: Synthesis and inhibitory activities against growing and dormant mycobacterium species. Bioorg. Med. Chem. Lett. 2009, 19, 1152-1154. [CrossRef] [PubMed]

19. Castle, R.N.; Witt, N.F.; Poe, C.F. The optical crystallographic properties of some sulfonamides and their derivatives. J. Am. Chem. Soc. 1949, 71, 228-231. [CrossRef] [PubMed]

20. Tsukamoto, T.; Yuhi, K. Studies on halogenosalicylaldehyde. I halogenosalicylaldehyde as reagent for primary amines. Yakugaku Zasshi 1958, 78, 706-709. [CrossRef]

21. Krátký, M.; Vinšová, J.; Novotná, E.; Wsól, V.; Ulmann, V.; Stolaříková, J.; Fernandes, S.; Bhat, S.; Liu, J.O. Salicylanilide derivatives block Mycobacterium tuberculosis through inhibition of isocitrate lyase and methionine aminopeptidase. Tuberculosis (Edinb.) 2012, 92, 434-439. [CrossRef] [PubMed]

Sample Availability: Samples of the compounds 1, $\mathbf{2} \mathbf{a}-\mathbf{q}$ are available from the authors.

(C) 2017 by the authors. Licensee MDPI, Basel, Switzerland. This article is an open access article distributed under the terms and conditions of the Creative Commons Attribution (CC BY) license (http:/ / creativecommons.org/licenses/by/4.0/). 